\title{
The last interglacial (Eemian) climate simulated by LOVECLIM and CCSM3
}

\author{
I. Nikolova, Q. Yin, A. Berger, U. K. Singh, and M. P. Karami \\ George Lemaitre Centre for Earth and Climate Research, Earth and Life Institute, Universite Catholique de Louvain, \\ 3 Place Louis Pasteur, 1348 Louvain-la-Neuve, Belgium
}

Correspondence to: I. Nikolova (irinanikolova@ mail.bg)

Received: 5 October 2012 - Published in Clim. Past Discuss.: 31 October 2012

Revised: 14 June 2013 - Accepted: 1 July 2013 - Published: 2 August 2013

\begin{abstract}
This paper presents a detailed analysis of the climate of the last interglacial simulated by two climate models of different complexities, CCSM3 (Community Climate System Model 3) and LOVECLIM (LOch-Vecode-Ecbilt-CLioagIsm Model). The simulated surface temperature, hydrological cycle, vegetation and ENSO variability during the last interglacial are analyzed through the comparison with the simulated pre-industrial (PI) climate. In both models, the last interglacial period is characterized by a significant warming (cooling) over almost all the continents during boreal summer (winter) leading to a largely increased (reduced) seasonal contrast in the Northern (Southern) Hemisphere. This is mainly due to the much higher (lower) insolation received by the whole Earth in boreal summer (winter) during this interglacial. The Arctic is warmer than PI through the whole year, resulting from its much higher summer insolation, its remnant effect in the following fall-winter through the interactions between atmosphere, ocean and sea ice and feedbacks from sea ice and snow cover. Discrepancies exist in the sea-ice formation zones between the two models. Cooling is simulated by CCSM3 in the Greenland and Norwegian seas and near the shelves of Antarctica during DJF but not in LOVECLIM as a result of excessive sea-ice formation. Intensified African monsoon is responsible for the cooling during summer in northern Africa and on the Arabian Peninsula. Over India, the precipitation maximum is found further west, while in Africa the precipitation maximum migrates further north. Trees and grassland expand north in Sahel/Sahara, more clearly seen in LOVECLIM than in CCSM3 results. A mix of forest and grassland occupies continents and expands deep into the high northern latitudes. Desert areas reduce significantly in the Northern Hemisphere, but increase
\end{abstract}

in northern Australia. The interannual SST variability of the tropical Pacific (El-Niño Southern Oscillation) of the last interglacial simulated by CCSM3 shows slightly larger variability and magnitude compared to the PI. However, the SST variability in our LOVECLIM simulations is particularly small due to the overestimated thermocline's depth.

\section{Introduction}

The Earth has experienced quite warm periods in the past (e.g., interglacials). Investigating the climate processes and feedbacks during these warm periods helps to improve our understanding of climate dynamics and to address key questions for the future, in particular given that the climate predicted to occur over the next centuries by the Intergovernmental Panel on Climate Change (IPCC, 2007) appears to be unprecedented over the last 150 years. The last interglacial (also called the Eemian interglacial or Marine Isotope Stage - MIS-5e) was a recent warm interglacial during which the Arctic experienced a marked summer warming, accompanied by sea-level rise and reduction in ice sheets (Otto-Bliesner et al., 2006a; Kukla et al., 2002; Bintanja et al., 2005; Jouzel et al., 2007; McKay et al., 2011). In terms of such climatic features, the last interglacial is often considered to be analogue to the future climate (e.g., Kukla et al., 1997), though this is still questionable in terms of its completely different astronomical configuration from today and the future (Berger and Loutre, 1996; Berger and Yin, 2012). There are still no detailed datasets compiled for MIS-5e except for the global temperature record of Turney and Jones (2010). This is related to the fact that creating a database based on individual 
records is complicated (Groll et al., 2005) due to the large uncertainties related to difficulties in estimating the duration of MIS-5e (Shackleton et al., 2003). Given its significance in helping to understand the future warming better, the last interglacial has been included recently in the Palaeoclimate Modelling Intercomparison Project (in its third phase, PMIP3, http://pmip3.lsce.ipsl.fr).

Yin and Berger $(2010,2012)$ have simulated the peak climates of the past nine interglacials with LOVECLIM (LOch-Vecode-Ecbilt-CLio-agIsm Model), an Earth system model of intermediate complexity. Using the same boundary conditions, Herold et al. (2012) simulated the climate of five stronger interglacials with the Community Climate System Model 3 (CCSM3), a comprehensive atmosphereocean general circulation model. These studies focused on the comparison between different interglacials. Because they used the same climate forcings, these studies provide ideal paired experiments for inter-model comparison, which would be interesting for the modeling community in particular given that LOVECLIM and CCSM3 are often used in climate/paleoclimate modeling and are of different complexity. The MIS-5e simulations provided by these studies and also included in Lunt et al. (2013) are analyzed here. Lunt et al. (2013) analyzed 23 snapshot simulations between 125 and $130 \mathrm{ka}$ BP performed by several climate models. They focus on the analysis of near-surface temperature, pointing out large regional deviations in the ensemble mean and between ensemble mean and proxy data. However, due to the large amount of models, it is difficult to address in detail the possible reasons for the simulated regional dissimilarities between the models. Given the increasing interest of the paleoclimate community in the last interglacial climate, detailed information about the simulated climates is needed and the mechanisms responsible for the changes of different climatic variables deserve to be investigated. A particularly careful analysis is required in the regions with the large deviations that could help us identify the reasons for these deviations and evaluate the climate sensitivity. This would also illuminate the strengths and weaknesses of the models in simulating various climate components and their feedback and ice-climate interactions. "Models that perform equally well for present-day may produce very different responses to likely changes in forcing in the future. This makes it vital to evaluate models, by comparing simulations of past climates against palaeo-observations and to analyse the causes of differences in model ability to reproduce observed climate changes in the past" (PMIP3, http://pmip3.lsce.ipsl.fr). Open questions still remain for the MIS-5e-simulated climate such as the following: are the polar amplification mechanisms and characteristics different between models and to what extent; how does the initial forcing influence the simulation of global monsoon and its relationship to the El Niño phenomenon; are key feedback processes simulated in agreement between different models and in line with proxy records? In this paper, we aim to answer the abovementioned questions by presenting a detailed regional and seasonal analysis for the surface climates of MIS-5e relative to the preindustrial (PI) period. We investigate the feedbacks of sea ice and snow cover, monsoon, vegetation and ENSO in the modeled climate system as plausible explanations for the regional similarities/dissimilarities simulated in both models, making it the first detailed intercomparison between CCSM3 and LOVECLIM models with emphasis on MIS-5e. We also give some quantitative comparison with proxy data reported in the literature, in order to determine where features are robust and where uncertainties are large.

The paper is organized as follows: in Sect. 2 we give a brief description of CCSM3 and LOVECLIM models and the prescribed boundary conditions. In Sect. 3 we discuss the similarities and differences in surface temperature between CCSM3 and LOVECLIM. In Sect. 4 we focus on African, Indian and East Asian monsoons. Vegetation is discussed in Sect. 5 and ENSO variability in Sect. 6. Conclusions are given in Sect. 7.

\section{Model descriptions}

\subsection{CCSM3 and BIOME4}

The Community Climate System Model 3 (CCSM3) is a coupled climate model with components representing the atmosphere, ocean, sea ice and land surface connected by a flux coupler (Collins et al., 2006). The atmospheric model is CAM3 (Collins et al., 2004). CAM3 has 26 vertical levels and a $3.75^{\circ} \times 3.75^{\circ}$ horizontal resolution which corresponds to T31 configuration. The land model CLM version 3.0 (Oleson et al., 2004) is integrated on the same horizontal grid as the atmosphere, with each grid box further divided into a hierarchy of land units and soil columns. The ocean model POP (Smith and Gent, 2002) uses a dipole grid with a horizontal resolution of $3^{\circ} \times 1.5^{\circ}$ in longitude and latitude, respectively. Vertically, the model has 25 levels that extend to $4.75 \mathrm{~km}$. The sea-ice model CSIM (Briegleb et al., 2004) is a dynamical model and has the same horizontal resolution as the ocean model POP. Ice sheets with present-day extent are prescribed. In the CCSM3 model framework there is no dynamically coupled vegetation module. Instead, vegetation is estimated using the offline vegetation model BIOME4 (Kaplan et al., 2003). CCSM3 output variables (such as temperature, precipitation, cloudiness, etc.) are used to force the BIOME4, to see what would be the vegetation distribution given the simulated climate. BIOME4 has 28 types of plants which we grouped into 3 major categories - trees, grass and desert.

\subsection{LOVECLIM}

LOVECLIM is a three-dimensional Earth system model of intermediate complexity (Goosse et al., 2010). The atmosphere model ECBilt is a quasi-geostrophic model with 
Table 1. Greenhouse gas concentrations and astronomical parameters used for the PI and the last interglacial simulations in both LOVECLIM and CCSM3.

\begin{tabular}{lcccccccc}
\hline & \multicolumn{3}{c}{ Greenhouse gases } & & \multicolumn{3}{c}{ Astronomical parameters } \\
\cline { 2 - 4 } \cline { 7 - 8 } $\begin{array}{l}\text { Date } \\
(\mathrm{kaBP})\end{array}$ & $\begin{array}{c}\mathrm{CO}_{2} \\
(\mathrm{ppmv})\end{array}$ & $\begin{array}{c}\mathrm{CH}_{4} \\
(\mathrm{ppbv})\end{array}$ & $\begin{array}{c}\mathrm{N}_{2} \mathrm{O} \\
(\mathrm{ppbv})\end{array}$ & $\begin{array}{c}\mathrm{CO}_{2} \mathrm{eq} \\
(\mathrm{ppmv})\end{array}$ & & Eccentricity & $\begin{array}{l}\text { Obliquity } \\
(\mathrm{deg})\end{array}$ & $\begin{array}{c}\text { Longitude } \\
\text { perihelion } \\
(\mathrm{deg})\end{array}$ \\
\hline 0 & 280 & 760 & 270 & 280 & & 0.01672 & 23.446 & 102.04 \\
127 & 287 & 724 & 262 & 284 & & 0.03938 & 24.04 & 275.41 \\
\hline
\end{tabular}

3 vertical levels and $5.625^{\circ} \times 5.625^{\circ}(\mathrm{T} 21)$ horizontal resolution (Opsteegh et al., 1998). CLIO is a primitiveequation, free-surface ocean general circulation model coupled to a thermodynamic/dynamic sea ice model (Goosse and Fichefet, 1999). The horizontal resolution is $3^{\circ} \times 3^{\circ}$ and there are 20 levels on the vertical in the ocean. VECODE is the vegetation model, developed by Brovkin et al. (1997). Based on annual mean values of several climatic variables, the VECODE model computes the evolution of the vegetation cover described as a fractional distribution of trees, grass and desert in each land grid cell with the same resolution as that of ECBilt. In this study, the atmosphere, ocean/sea ice and vegetation are interactively coupled, and the ice sheets are prescribed with present-day extent.

\subsection{Boundary conditions for the equilibrium experiments}

In our experiments, MIS-5e has the astronomical configuration of $127 \mathrm{kaBP}$. It is worth noting that several dates around the peak of the last interglacial have been used to select the insolation forcing in previous studies (see the summary in Lunt et al, same issue). According to the strategy of Yin and Berger $(2010,2012)$, insolation at $127 \mathrm{ka}$ BP was used in our MIS-5e experiments of both LOVECLIM and CCSM3. This is because, following the hypothesis that an interglacial is associated with a strong summer insolation in Northern Hemisphere $(\mathrm{NH})$, the insolation was taken at the dates when NH summer occurred at perihelion just preceding the interglacial peak, taking into account a few thousands of years of lag between the forcing and climatic response. Compared to PI, MIS-5e climate is driven by much larger eccentricity (0.03937 vs. 0.01672 for PI) and obliquity $\left(24.040^{\circ}\right.$ vs. $23.446^{\circ}$ for PI) (Berger, 1978). NH summer occurring at perihelion, a situation opposite to PI, leads to much more insolation received on Earth during boreal summer (Fig. 1). The $\mathrm{CO}_{2}$ equivalent concentration (contribution of $\mathrm{CO}_{2}, \mathrm{CH}_{4}$ and $\mathrm{N}_{2} \mathrm{O}$ ) is taken to be $284 \mathrm{ppmv}$ in MIS-5e and 280 ppmv in PI (Table 1). As a result, the differences observed between MIS-5e and PI climate are mainly driven by the strong astronomically induced seasonal forcing of MIS-5e.

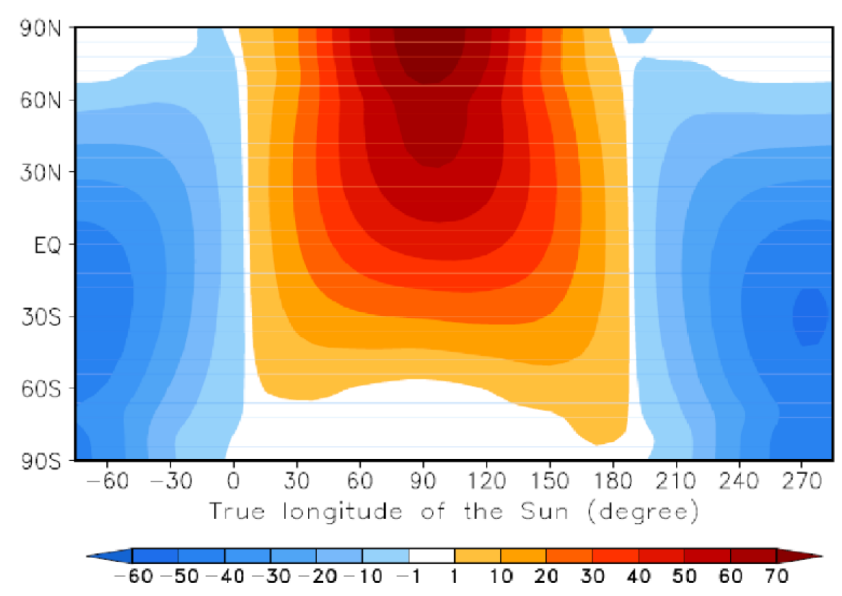

Fig. 1. Difference in the latitudinal/seasonal insolation distribution $\left(\mathrm{W} \mathrm{m}^{-2}\right.$ ) between $127 \mathrm{ka} \mathrm{BP}$ and PI. The true longitudes 0 and $180^{\circ}$ correspond to the spring and fall equinoxes, respectively; 90 and $270^{\circ}$ are for the summer and winter solstices, respectively.

In CCSM3, the pre-industrial climate is a $900 \mathrm{yr}$ continuation run from year 400 of the simulation conducted at the National Center for Atmospheric Research (Otto-Bliesner et al., 2006b). The MIS-5e simulation is initiated from PI simulation at year 500 and run for $1000 \mathrm{yr}$. In LOVECLIM, the simulations of PI and MIS-5e are both $1000 \mathrm{yr}$-long equilibrium runs. The results of the last $100 \mathrm{yr}$ are used for the analysis.

\section{Simulated surface temperature anomalies}

Compared to PI, the global annual mean surface temperature of MIS-5e is $0.5^{\circ} \mathrm{C}$ warmer in LOVECLIM and $0.2^{\circ} \mathrm{C}$ cooler in CCSM3 (Table 2). Terrestrial and marine records indicate a warming of about $1.9^{\circ} \mathrm{C}$ during MIS-5e relative to the preindustrial period (Turney and Jones, 2010), which is underestimated by LOVECLIM and CCSM3. In addition to the possible uncertainty in the estimation based on proxy records, one of the reasons might be due to the lack of interactive ice sheets in both models. Holden et al. (2010) investigated the effect of warming in Antarctica when accounting for dynamic ice sheets. They found that the surface temperature 
Table 2. Global mean surface temperature $\left({ }^{\circ} \mathrm{C}\right)$ of MIS-5e and PI in CCSM3 and LOVECLIM. DJF and JJA stand for December-JanuaryFebruary and June-July-August, respectively.

\begin{tabular}{|c|c|c|c|c|c|c|}
\hline & \multicolumn{2}{|c|}{ Annual } & \multicolumn{2}{|r|}{ DJF } & \multicolumn{2}{|c|}{ JJA } \\
\hline & CCSM3 & LOVECLIM & CCSM3 & LOVECLIM & CCSM3 & LOVECLIM \\
\hline MIS-5e & 12.3 & 16.5 & 9.6 & 13.7 & 15.0 & 19.7 \\
\hline PI & 12.5 & 16.0 & 10.8 & 14.1 & 14.1 & 18.2 \\
\hline Anomaly & -0.2 & 0.5 & -1.2 & -0.4 & 0.9 & 1.4 \\
\hline
\end{tabular}

in East Antarctica increased from 1.4 (Dome C) and $2.2^{\circ} \mathrm{C}$ (Dome F) to 5 (Dome C) and $4.9^{\circ} \mathrm{C}$ (Dome F) caused by the retreat and meltwater of the West Antarctic Ice Sheet (WAIS). In the NH, according to Otto-Bliesner et al. (2006a), when the Greenland ice sheet is completely removed, there is an additional summer warming of $7^{\circ} \mathrm{C}$ to more than $10^{\circ} \mathrm{C}$ localized over Greenland, and the freshwater forcing of inserting 0.1 sverdrup of water in the North Atlantic over $100 \mathrm{yr}$ yields an annual cooling of $1.5^{\circ} \mathrm{C}$ south of Greenland. In spite of this freshwater-induced cooling, the summer temperature anomalies over Greenland remain positive. Lunt et al. (2004) also found that the effect of melted Greenland is local for temperature (directly related to changes in altitude and albedo of the surface) and precipitation, and more widespread for circulation (response to changed orography) but the "principal effect of removing the Greenland ice sheet is relatively localised". They show that December-JanuaryFebruary (DJF) surface temperature decreases over Barents Sea $\left(2{ }^{\circ} \mathrm{C}\right.$ for $2 \mathrm{~m}$ height temperature) as a result of changes in the near-surface meridional wind speed. In the case of melted Greenland, cold air from the pole is advected to the south. This cooling along with the freshening of the North Atlantic increases the sea-ice formation and retains sea ice in June-July-August (JJA) as mentioned by Lunt et al. (2004). However, all these sensitivity studies are for a complete melting of Greenland ice sheet; therefore the effects of the MIS5e Greenland melting would be much smaller and would be important mainly for the regions over and around Greenland. Nevertheless, the shortcoming of prescribing ice sheet to present-day extent should be kept in mind when modelproxy comparison is made.

The simulated differences could also be related to the different level of details of physical processes that may not consider properly the feedbacks in the climate system. Global cooling is simulated in DJF and warming in JJA by both models. LOVECLIM simulates consistently warmer climate than CCSM3. This might be related to the temperature biases in both models and through feedbacks from the modeled climate system. Goosse et al. (2010) report that tropical regions in LOVECLIM are too warm and the temperature gradient between the eastern and western Pacific is underestimated as a result of a warmer eastern Pacific. In CCSM3, Collins et al. (2006) report colder northern $\left(60-90^{\circ} \mathrm{N}\right)$ and southern $\left(60-90^{\circ} \mathrm{S}\right)$ regions. Along with the missing feedback from dynamic ice sheets, the feedback from vegetation could also affect the temperature through albedo change. As we discuss in Section 5, trees expanded deep into the northern high latitudes, replacing grassland. The lack of interactive vegetation in CCSM3 could cause unrealistic surface temperature because of the missing response during the replacement. According to Brovkin (2002), climate exerts a major control on the spatial distribution of vegetation types, while vegetation influences climate via changes in the physical properties of the land surface such as albedo, biogeophysical mechanisms, roughness and atmospheric gas composition. For example Crucifix and Loutre (2002) show that during boreal winters the albedo of snow in the presence of grass is about 0.8 (contributing to the cooling of the atmosphere). The presence of trees, however, reduces the albedo to 0.4 and consequently increases the temperature in the atmosphere. Denman et al. (2007) also show that "Shorter vegetation with more leaves has the most latent heat flux and the least sensible flux. Replacement of forests with shorter vegetation together with the normally assumed higher albedo could then cool the surface". Vegetation-induced cooling/warming through albedo change is also discussed in several other studies (Ganopolski et al., 1998; Claussen, 1998; Claussen et al., 2006; Kubatzki et al., 2000).

\subsection{JJA surface temperature anomalies}

CCSM3 and LOVECLIM simulate a significant warming over almost all the continents in JJA during MIS-5e, with the largest warming over the NH lands (Fig. 2). The statistical significance (at the $99 \%$ confidence level) of the surface temperature anomalies, calculated using a Student $t$ test, is also shown in the figure. The same $t$ test is applied for the simulated DJF and annual surface temperature anomalies and JJA and DJF precipitation anomalies.

The large continental warming during MIS-5e results from its much higher insolation during boreal summer. Radiative forcing induces a temperature response larger over land than over the ocean due to the large thermal capacity of the ocean. Differences in heat capacity can explain the large variation between land and ocean surface during boreal summer. Significant warming is simulated over North America, Asia and Europe, in line with reconstructed surface temperatures (de Beaulieu and Reille, 1992; Hahne et al., 1994; Laberyie et al., 
a)

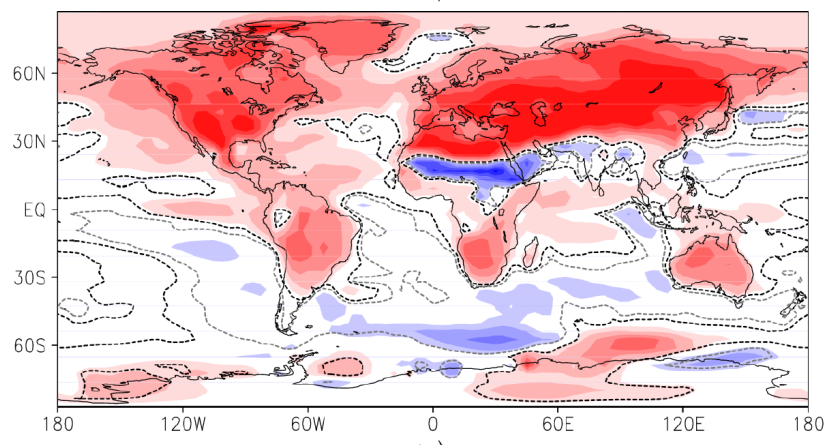

b)

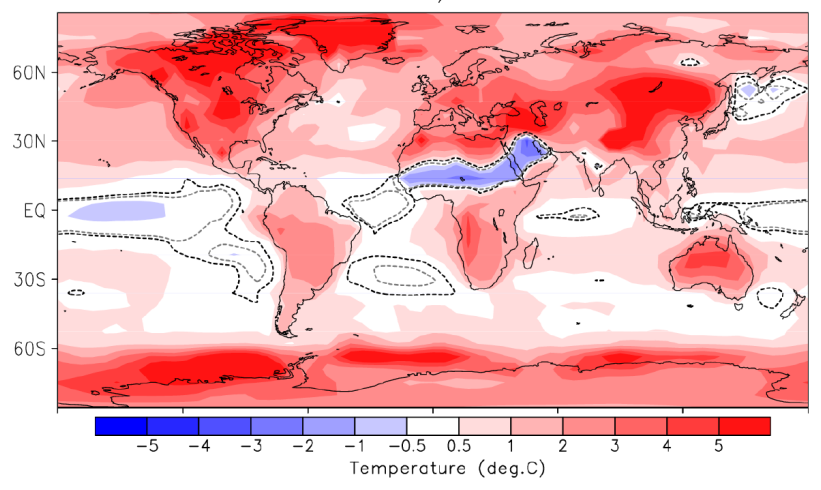

Fig. 2. JJA surface temperature $\left({ }^{\circ} \mathrm{C}\right)$ anomaly (MIS-5e minus PI) simulated by (a) CCSM3 and (b) LOVECLIM. Temperature anomaly between black and grey dashed lines is statistically insignificant.

1996; Mamakowa, 1989). Table 3 gives some reconstructed surface temperature anomalies at different locations as well as the corresponding results in both models. The significant warming over Asia is in line with the loess records in China which indicate warm and humid conditions during the last interglacial (Porter, 2001; Guan et al., 2007). Over China, both CCSM3 and LOVECLIM simulate cooler annual temperature during MIS-5e, but warmer summer, confirming that the strength of the soil development in the loess reflects mostly the summer climatic conditions. Cooling is simulated over the monsoon region of northern Africa, related to a strengthened African monsoon (see Sect. 4). The cooling is mainly driven by increased low-level moisture and latent heat flux in both models, increased cloudiness and precipitation in CCMS3 and increase in precipitation and vegetation feedback in LOVECLIM. Fischer and Jungclaus (2010) also simulated a temperature decrease in the tropics attributed to the same intensification of the African monsoon system. Intensive warming is simulated in the Arctic (for 60 to $90^{\circ} \mathrm{N}$ ) in both models. The simulated warming in CCSM3 is $2.2^{\circ} \mathrm{C}$ and in LOVECLIM is $3{ }^{\circ} \mathrm{C}$, in agreement with the warming of $2.4{ }^{\circ} \mathrm{C}$ found by means of numerical simulations in Otto-Bliesner et al. (2006a). This warming is caused by the high insolation at the top of the atmosphere during JJA and

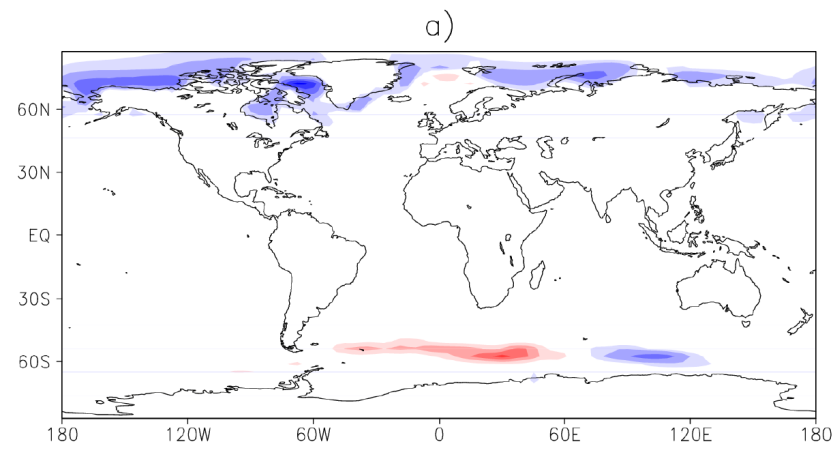

b)

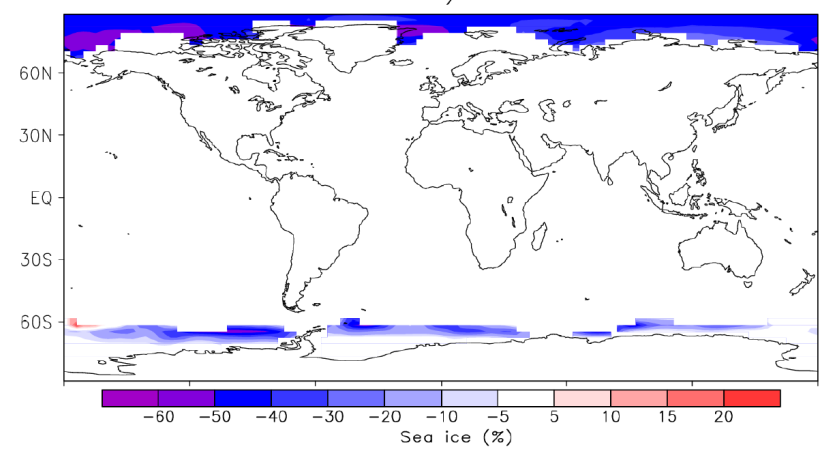

Fig. 3. JJA sea-ice fraction (\%) anomaly simulated by (a) CCSM3 and (b) LOVECLIM.

the large reduction of the sea ice and snow cover. Less sea ice is simulated in both models - about $-40 \%$ in CCSM3 and up to $-60 \%$ in LOVECLIM (Fig. 3). The sea-ice models of CCSM3 and LOVECLIM are both dynamic and thermodynamic. There is only one sea-ice thickness category in LOVECLIM, but there are five in CCSM3. The approach of including a finite set of thickness categories has been recognized to improve the computation of ice growth and melting rates evolving in response to thermal and mechanical forcings (Fichefet and Maqueda, 1997). Differences in parameterizations of the sea-ice processes not only influence the simulated mean state but also modify the ice-cover response to external disturbances. Therefore, the difference in sea-ice model complexity at least partly contributes to the different sea-ice response in the two models. Additionally, the reduction of snow cover (not shown) in Greenland and on the islands west of Greenland is simulated to be up to $8 \mathrm{~m}$ in LOVECLIM and up to $1 \mathrm{~m}$ in CCSM3. The strong feedback from the reduction of snow cover over land, next to the external astronomical forcing, could partly explain why Greenland is on average warmer in LOVECLIM $\left(5.3^{\circ} \mathrm{C}\right)$ than in CCSM3 $\left(3.4^{\circ} \mathrm{C}\right)$. The simulated warming for $75.10^{\circ} \mathrm{N}$ and $42.32^{\circ} \mathrm{W}$ in CCSM 3 is $3.8^{\circ} \mathrm{C}$ and in LOVECLIM is $6.3^{\circ} \mathrm{C}$, in line with the warming of about $5^{\circ} \mathrm{C}$ found in ice-core records (Andersen et al., 2004). Duplessy et al. (2007) point out that the summer temperatures were 2 to $5^{\circ} \mathrm{C}$ warmer than today in the North Atlantic, Greenland (Andersen et al., 2004), Alaska (Muhs et al., 2001) and Asia (Lozhkin and 
Table 3. Reconstructed surface temperature anomaly (difference between MIS-5e and PI) based on proxy records and the corresponding simulated anomaly by CCSM3 and LOVECLIM.

\begin{tabular}{|c|c|c|c|c|}
\hline Study & Coordinates/area & $\begin{array}{l}\Delta T \\
{ }^{\circ} \mathrm{C}\end{array}$ & $\begin{array}{l}\mathrm{CCSM} 3 \\
{ }^{\circ} \mathrm{C}\end{array}$ & $\begin{array}{l}\text { LOVECLIM } \\
{ }^{\circ} \mathrm{C}\end{array}$ \\
\hline \multicolumn{5}{|c|}{ JJA } \\
\hline Anderson et al. (2004) & $42.32^{\circ} \mathrm{W} ; 75.10^{\circ} \mathrm{N}$ & 5 & 3.8 & 6.3 \\
\hline Andreev et al. (2004) & $141^{\circ} \mathrm{E} ; 73^{\circ} \mathrm{N}$ & $4-5$ & 1.6 & 2.3 \\
\hline de Beaulieu and Reille (1992) & $6.5^{\circ} \mathrm{E} ; 47.73^{\circ} \mathrm{N}$ & 1.7 & 4.6 & 3.4 \\
\hline Hahne et al. (1994) & $7.57^{\circ} \mathrm{E} ; 52.4^{\circ} \mathrm{N}$ & 1.4 & 2.6 & 2.7 \\
\hline Labeyrie et al. (1996) & $96.28^{\circ} \mathrm{E} ; 46^{\circ} \mathrm{S}$ & 3 and more & -0.07 & 0.4 \\
\hline Lozkhin and Anderson (1995) & $132-180^{\circ} \mathrm{E} ; 60-70^{\circ} \mathrm{N}$ & $4-8$ & 2.9 & 1.8 \\
\hline Mamakowa (1989) & $\sim 16.57^{\circ} \mathrm{E} ; \sim 50.88^{\circ} \mathrm{N}$ & 2.5 & 4.6 & 3.7 \\
\hline Muhs et al. (2001) & $148-164^{\circ} \mathrm{W} ; 58-66^{\circ} \mathrm{N}$ & $0-2$ & 0.4 & 2.1 \\
\hline Otto-Bliesner et al. (2006a)* & $0-360^{\circ} \mathrm{E} ; 60-90^{\circ} \mathrm{N}$ & 2.4 & 2.2 & 3 \\
\hline Pahnke et al. (2003) & $174.55^{\circ} \mathrm{E} ; 45.3^{\circ} \mathrm{S}$ & -2 & -0.01 & 0.2 \\
\hline \multicolumn{5}{|c|}{ DJF } \\
\hline Bianchi and Gersonde (2002) & $40^{\circ} \mathrm{E} ; 52-59^{\circ} \mathrm{S}$ & $2-3.5$ & 0.2 & 0.6 \\
\hline Crosta et al. (2004) & $160^{\circ} \mathrm{E} ; 55^{\circ} \mathrm{S}$ & $5-6$ & 0.1 & 0.2 \\
\hline \multirow[t]{2}{*}{ Lozkhin and Anderson (1995) } & $132-180^{\circ} \mathrm{E} ; 60-70^{\circ} \mathrm{N}$ & 4 & -0.6 & 3.7 \\
\hline & $0-360^{\circ} \mathrm{E} ; 50-60^{\circ} \mathrm{S}$ & & -0.1 & 0.7 \\
\hline \multicolumn{5}{|c|}{ Annual } \\
\hline EPICA (Jouzel et al., 2007) & $123^{\circ} \mathrm{E} ; 75^{\circ} \mathrm{S}$ & $2-4$ & -0.2 & 0.8 \\
\hline \multirow[t]{3}{*}{ Vostok (Petit et al., 1999) } & $106^{\circ} \mathrm{E} ; 78^{\circ} \mathrm{S}$ & 2.3 & -0.1 & 0.8 \\
\hline & $0-360^{\circ} \mathrm{E} ; 60-90^{\circ} \mathrm{S}$ & & -0.2 & 1.7 \\
\hline & $0-360^{\circ} \mathrm{E} ; 70-60^{\circ} \mathrm{S}$ & & -0.2 & 1.5 \\
\hline
\end{tabular}

* model study.

Anderson, 1995) (Table 3). Reconstructed surface temperature anomaly (difference between MIS-5e and PI) based on proxy records and the corresponding simulated anomaly by CCSM3 and LOVECLIM. Anderson et al. (2006) reviewed the Arctic climate during the last interglacial based on reconstructed proxy records in terrestrial and marine archives. These reconstructions show that the Arctic summer temperatures were about $4-5{ }^{\circ} \mathrm{C}$ warmer than today and associated with a decrease in summer sea ice.

Over Antarctica the simulated mean surface temperature anomaly between 70 and $90^{\circ} \mathrm{S}$ is $0.4^{\circ} \mathrm{C}$ in CCSM3 and $3.1^{\circ} \mathrm{C}$ in LOVECLIM. This warming is driven by the global warmth during MIS-5e and the extent of sea ice (Fig. 3). Warming is found between both model simulations near the shelves of Antarctica in the regions of decreased sea-ice concentration. The decrease of the sea-ice concentration causes a release of heat from the ocean into the atmosphere due to its lowered insulation. CCSM3 simulates more sea ice, extending further to the north during MIS-5e than does LOVECLIM. This is related to the enhanced meridional temperature gradient between Africa and the Southern Ocean and increased upper-level zonal wind (Otto-Bliesner et al., 2006b; Yeager et al., 2006; Gent et al., 2011; Herold et al., 2012). In west Antarctic Peninsula, LOVECLIM underestimates the sea-ice extent (Goosse et al., 2010), leading to larger positive temperature differences with PI than in CCSM3. Over the Southern Ocean LOVECLIM SST anomaly remains higher than the anomaly in CCSM3, but with both being lower than the findings in proxy records. Marine records show a warming of about $2{ }^{\circ} \mathrm{C}$ over the Southern Ocean during the last interglacial period (Labeyrie et al., 1996; Pahnke et al., 2003).

\subsection{DJF surface temperature anomalies}

During boreal winter both models show cooler continents in MIS-5e than at PI (Fig. 4), as a consequence of the reduced insolation. East of Japan, a negative anomaly is simulated in CCSM3 associated with increased sea-ice formation, but not in LOVECLIM (Fig. 5). Over the oceans, the sea-surface temperature (SST) anomalies are weak in both models (around $-0.5^{\circ} \mathrm{C}$ ). In the southern polar region (for 60-90 ${ }^{\circ} \mathrm{S}$ ), CCSM3 and LOVECLIM simulate an average cooling of -1.8 and $-0.3^{\circ} \mathrm{C}$, respectively. However, over the Southern Ocean, both models simulate areas of warming. Between 52 and $59^{\circ} \mathrm{S}$ and $40^{\circ} \mathrm{E}$ and $35^{\circ} \mathrm{W}$, CCSM3 and LOVECLIM simulate a warming of 0.2 and $0.6^{\circ} \mathrm{C}$, respectively (see Table 3 ). Nonetheless, both models underestimate the warming of $2-3.5^{\circ} \mathrm{C}$ given in the proxy record by Bianchi and Gersonde (2002). Similarly, around $55^{\circ} \mathrm{S}$ at 


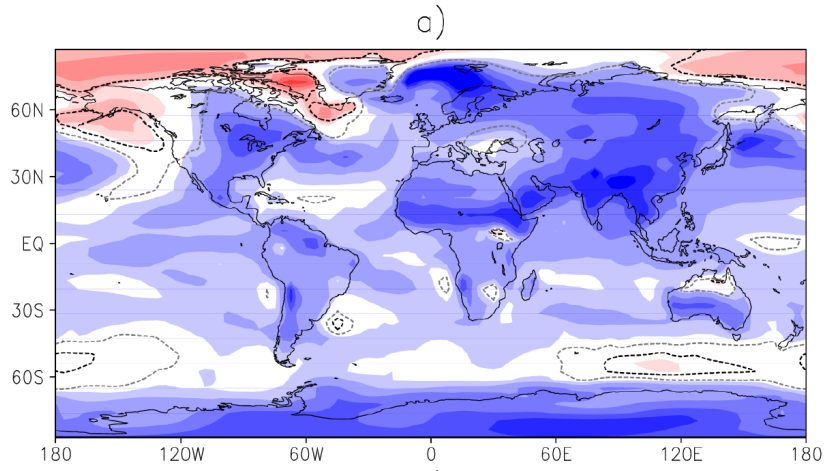

b)

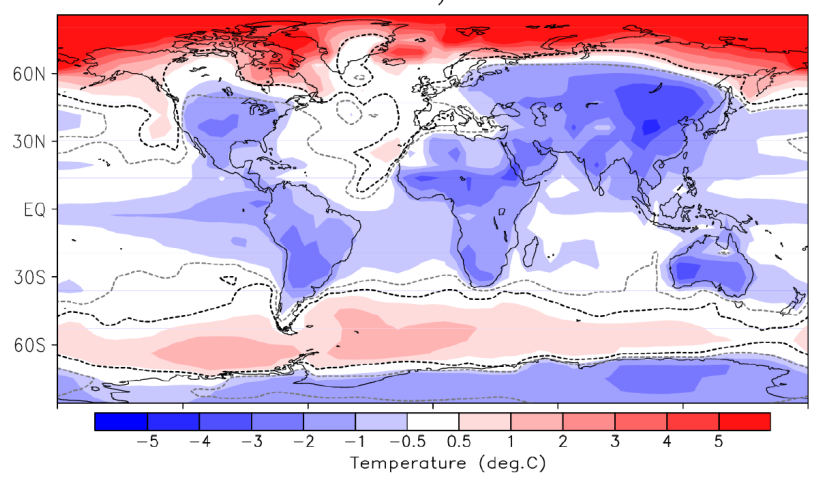

Fig. 4. DJF surface temperature $\left({ }^{\circ} \mathrm{C}\right)$ anomaly simulated by (a) CCSM3 and (b) LOVECLIM. Temperature anomaly between black and grey dashed lines is statistically insignificant.

$160^{\circ} \mathrm{E}, \mathrm{CCSM} 3$ and LOVECLIM underestimate the warming of $5-6{ }^{\circ} \mathrm{C}$ found in Crosta et al. (2004).

Over most of the Arctic region, the surface temperature anomalies agree pretty well in both models with a smooth south-north transition from cooling to warming. The winter Arctic SST in MIS-5e remains higher than in PI, a result of the higher summer insolation and its delayed impact in winter through the ocean/sea-ice system, the so-called summer remnant effect (Yin and Berger, 2012). Fischer and Jungclaus (2010) also point out that the reduced/absent seaice cover over the Barents Shelf and on the east coast of Greenland cannot act as an insulator between the ocean and the atmosphere and heat from the ocean is released in DJF. The Arctic, for $60-90^{\circ} \mathrm{N}$, remains warmer in LOVECLIM, partly related to the snow cover change, too. In LOVECLIM the anomaly is $-0.5 \mathrm{~m}$ and in CCSM 3 it is $-0.01 \mathrm{~m}$. This is mainly attributed to the melting of snow over Greenland where the role of snow depth is important due to its effect on albedo. A vegetation feedback could also be related to the simulated warmth in LOVECLIM. LOVECLIM surface temperature in MIS-5e remains higher than in CCSM3 in the areas of expanded vegetation during MIS-5e. However, CCSM3 does not account for the MIS-5e vegetation; hence it will be difficult to assess its effect on surface temperature. Discrepancy on the sign of the anomalies between

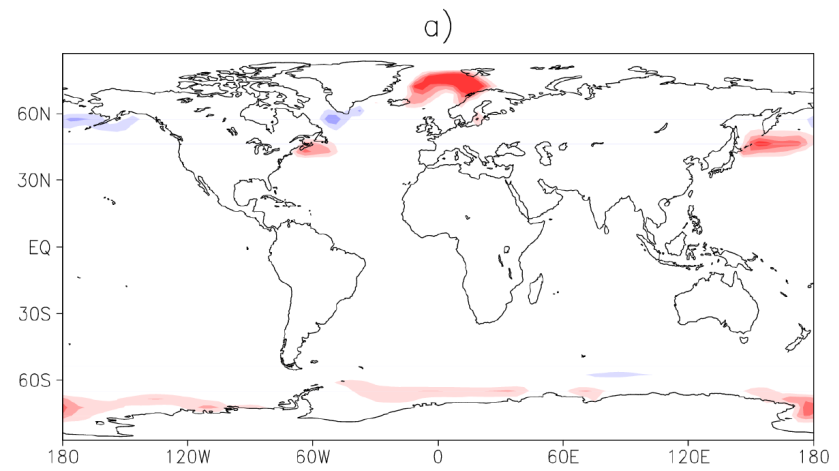

b)

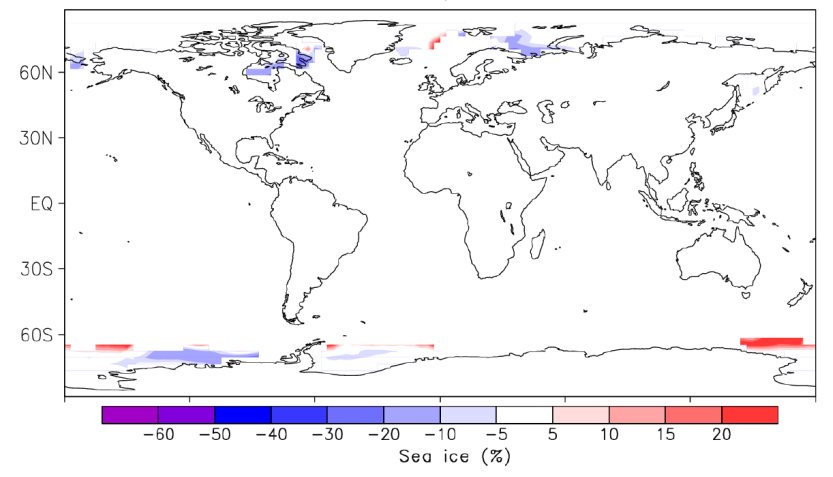

Fig. 5. DJF sea-ice fraction (\%) anomaly simulated by (a) CCSM3 and (b) LOVECLIM.

the two models happens in the area of Svalbard archipelago from 74 to $81^{\circ} \mathrm{N}$ and from 10 to $35^{\circ} \mathrm{E}$. CCSM3 simulates a large cooling of $-4.5^{\circ} \mathrm{C}$, while LOVECLIM simulates a warming of $6.4^{\circ} \mathrm{C}$, mirrored also in the sea-ice concentration. CCSM3 shows a sea-ice expansion with its maximum positive anomaly (more than $20 \%$ ) during DJF. Herold et al. (2012) first pointed out the appearance of such intensified sea-ice expansion after an $800 \mathrm{yr}$ run. A possible reason for this sea-ice expansion could be related to the freshening and cooling of the North Atlantic Current. This would induce two effects: a sea-ice increase at around $45^{\circ} \mathrm{N}$ and $60^{\circ} \mathrm{W}$ and a transport of fresh and cold waters to the Greenland and Norwegian seas resulting in an increased sea-ice formation. The decrease in salinity (not shown) in CCSM3 and LOVECLIM as a result of sea-ice melting during boreal summer indicates a freshening that is consistent with the weakening of the Atlantic Meridional Overturning Circulation (AMOC) simulated in both models during MIS5e relative to PI. For example, in LOVECLIM, the much higher NH summer insolation during MIS-5e reduces significantly the NH sea-ice concentration and increases the temperature of the source region of North Atlantic deep water all year round, leading to a weaker North Atlantic deep water formation during MIS-5e than PI (Yin, 2013). Oppo et al. (2001) discuss that changes in latitudinal temperature gradients may induce changes in large-scale wind fields with 
"far-reaching influences". Such influences include, for example, changes in the strength and/or position of the Atlantic Meridional Overturning Circulation (Hodell et al., 2009), changes in temperature and salinity in areas of deep water formation, etc. Bauch et al. (1999) investigated the seasurface temperature in the area of the Iceland, Norwegian and Greenland seas based on proxy records of planktonic foraminiferal assemblages, $\mathrm{CaCO}_{3}$ content, oxygen isotopes of foraminifera and iceberg-rafted debris. Based on this analysis, it was shown that MIS-5e SST was warmer in comparison with the Holocene in the Iceland Sea, but remained cooler north of $70^{\circ} \mathrm{N}$ due to a reduction in the northward flow of Atlantic surface water, less outflow of polar waters from the Arctic Ocean and steeper meridional SST gradient. It was also suggested that a relatively cold northern Eurasian margin could have resulted in more glaciated areas with consequences for the atmospheric circulation patterns, sea-ice cover and albedo.

\subsection{Annual surface temperature anomalies}

Figure 6 shows the annual surface temperature differences between MIS-5e and PI simulated by CCSM3 and LOVECLIM. Significant warming is simulated in high latitudes by both models, with the largest anomalies towards the North Pole. This warming is a result of the high insolation during summer and the summer remnant effect during winter (Yin and Berger, 2012). However, over the Southern Ocean, the insolation change during DJF is too small to trigger a summer remnant effect and the annual warming is driven by the global warmth during JJA. A warmer Southern Ocean and an annually warmer Antarctica are modeled in LOVECLIM, but not in CCSM3. The average anomaly for the area $70-90^{\circ} \mathrm{S}$ is $1.5^{\circ} \mathrm{C}$ in LOVECLIM and $-0.2^{\circ} \mathrm{C}$ in CCSM3 (see Table 3). The warming in LOVECLIM is in line with ice-core records from the Antarctic Plateau. The Vostok ice core shows an average warming of $2.3^{\circ} \mathrm{C}$ (Petit et al., 1999), which was confirmed later by the EPICA ice-core record showing a $2-4{ }^{\circ} \mathrm{C}$ warming during MIS-5e compared to PI (Jouzel et al., 2007; Masson-Delmotte et al., 2010).

Overall, the annual mean response of the two models is small, but the seasonal response is much clearer. This is also discussed by Lunt et al. (2013) in their model intercomparison. They stress that the agreement between models and proxy records is far from perfect and it is important to assess the uncertainties in these proxy records. LOVECLIM simulates higher seasonal and therefore annual mean surface temperatures than CCSM3. Around Svalbard archipelago the strong DJF signal, simulated in CCSM3, is imprinted on the annual surface temperature whereas the JJA signal dominates the LOVECLIM simulations in this region. The uncertainties remain large in the areas of modeled sea-ice formation and need to be further addressed because the majority of the seasonal and annual temperature variations occur at the sea-ice boundaries.

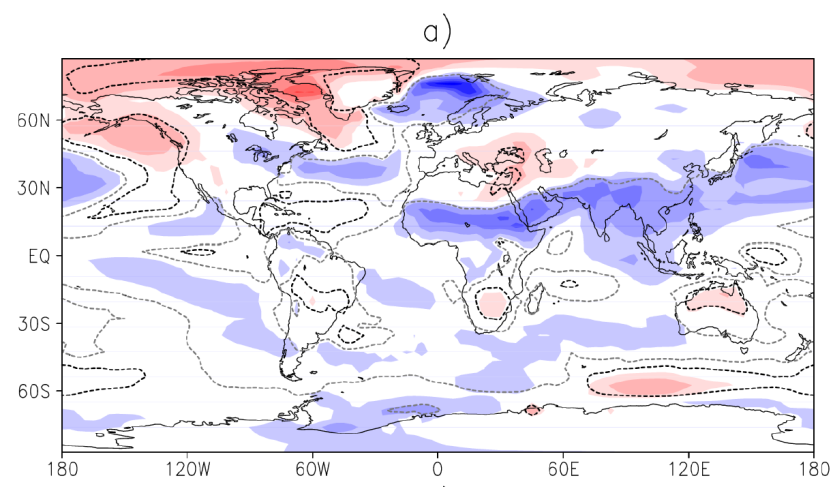

b)

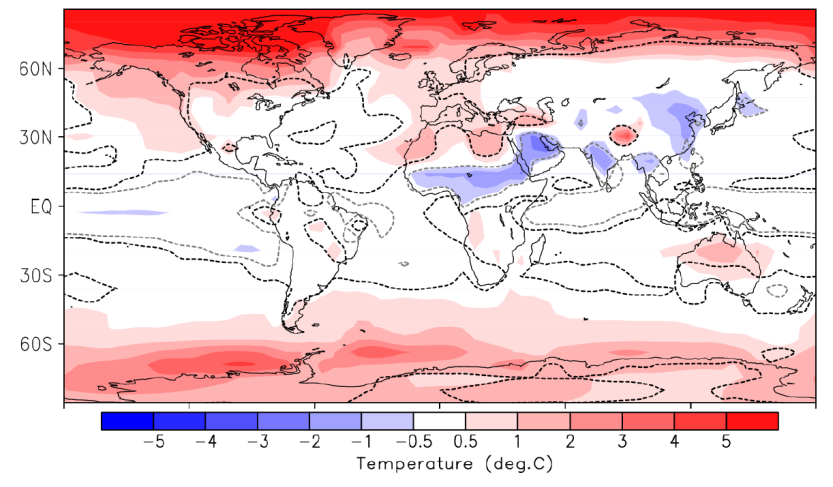

Fig. 6. Annual surface temperature $\left({ }^{\circ} \mathrm{C}\right)$ anomaly simulated by (a) CCSM3 and (b) LOVECLIM. Temperature anomaly between black and grey dashed lines is statistically insignificant.

\section{Simulated precipitation anomalies}

\subsection{JJA precipitation anomalies}

Monsoon is the major manifestation of the seasonal cycle in the tropical regions, and there is a wide range of evidence from marine and terrestrial data that the monsoon characteristics are affected by changes in the Earth's astronomical parameters (de Noblet et al., 1996; Kubatzki et al., 2000; Montoya et al., 2000) during the last Interglacial. Both CCSM3 and LOVECLIM simulate significantly stronger northern monsoon during MIS-5e. Compared to PI (Fig. 7), the rainfall increases by $4-5 \mathrm{~mm} \mathrm{day}^{-1}$ during MIS-5e over central Africa and Saudi Arabia and by $3-4 \mathrm{~mm} \mathrm{day}^{-1}$ over India, Tibet, southwestern China and the northern part of South America. These results are in good agreement with the simulated heavy precipitation and proxy-based reconstruction reported in Prell and Kutzbach (1987). The precipitation change is relatively small over the extra-tropical regions.

A strong northward migration of the Intertropical Convergence Zone (ITCZ) was simulated in equatorial Africa with a significant precipitation increase over the Sahel and southern Sahara, but less over tropical Africa south of $8^{\circ} \mathrm{N}$. The sources of water for our simulated African monsoon are from the tropical Atlantic and from local recycling further inland. 

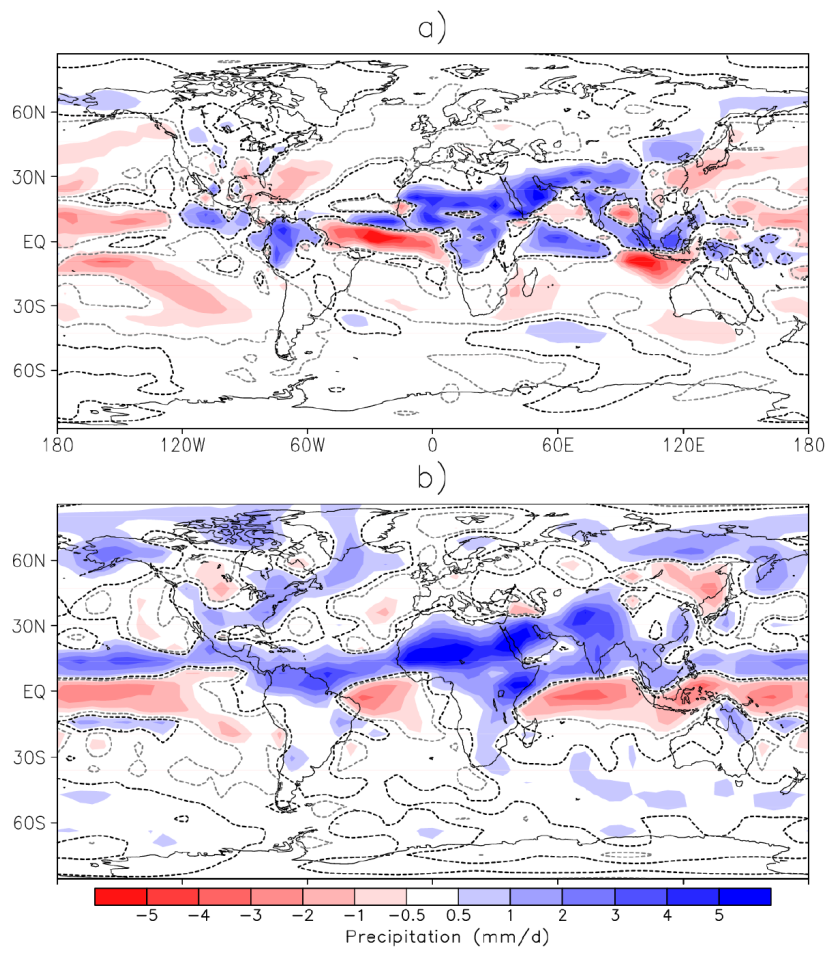

Fig. 7. JJA precipitation $\left(\mathrm{mmday}^{-1}\right)$ anomalies simulated by (a) CCSM3 and (b) LOVECLIM. Precipitation anomaly between black and grey dashed lines is statistically insignificant.

The amount of water vapor coming from both sources is enhanced during the last interglacial due to increased low-level wind speeds and land evaporation rates, as discussed also in Braconnot et al. (2008). Indeed the distribution of precipitation depends very much on the location of moisture sources and on wind speed. Compared to PI, the increased low-level wind speed and moisture transport during MIS-5e are consistent in both model simulations, showing higher tropical boreal summer precipitation.

Over Asia the most prominent shifts in precipitation maxima are related to the northward displacement of the ITCZ. A northward shift of the ITCZ during JJA is seen from the eastern Pacific to India, consistent with a greater increase in JJA insolation in the NH compared to the SH. The warmer summer and colder winter lead to larger NH seasonal contrast. Large amounts of water vapor are advected from moisture sources located over the Arabian Sea, the Indian Ocean and western Pacific to southern Asia. Moreover the northward penetration of moist air is limited by the Tibetan Plateau, which prevents it from being transported further north. As a consequence Asia experienced stronger summer monsoon in MIS-5e. The southern and western branch of the North Pacific high strengthens the East Asian summer monsoon as seen from an increase in onshore winds and in precipitation in northern China for CCSM3 and in most of China in LOVECLIM. Southwesterly surface wind over India, cross

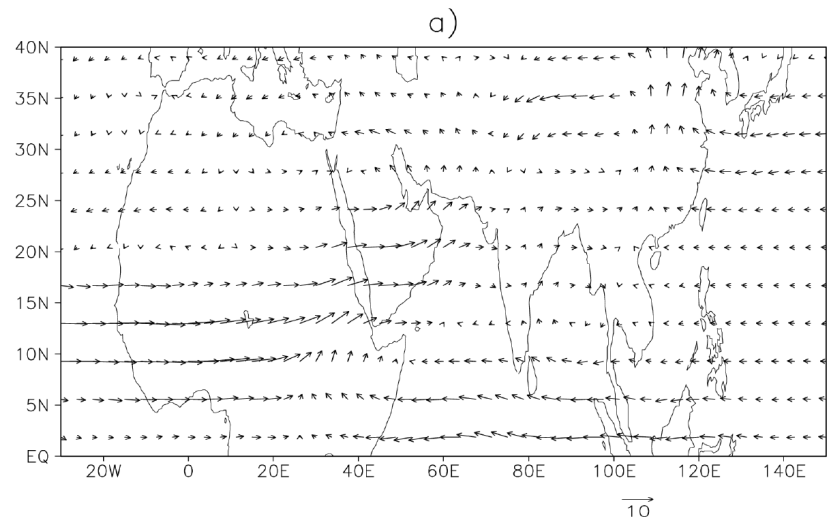

b)

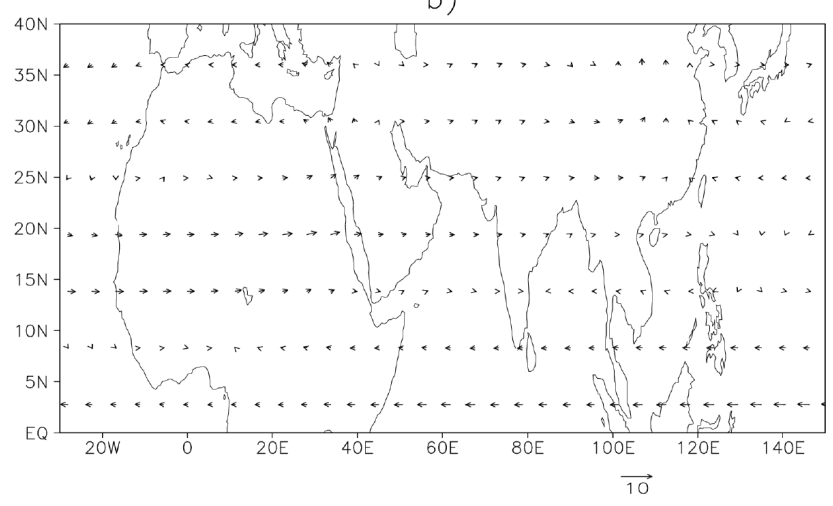

Fig. 8. JJA surface wind $\left(\mathrm{m} \mathrm{s}^{-1}\right)$ anomaly for region $0-40^{\circ} \mathrm{N}$ and $30^{\circ} \mathrm{W}-150^{\circ} \mathrm{E}$ in (a) CCSM3 and (b) LOVECLIM.

equatorial flow over the Indian Ocean and anticyclonic circulation over the western North Pacific Ocean are stronger in CCSM3 than in LOVECLIM (Fig. 8). The surface wind and moisture transport (not shown) during MIS-5e are in good agreement with water vapor supply over east Asia coming mainly from the Indian Ocean and secondarily from the South China Sea and western Pacific Ocean.

Monsoon rainfall distribution is closely related to the large-scale atmospheric circulation. The simulated upperlevel $(200 \mathrm{hPa})$ tropical easterly jet (TEJ) anomaly is stronger in both models during MIS-5e than during PI (Fig. 9). The mean change over the region of $5-20^{\circ} \mathrm{N}$ and $30^{\circ} \mathrm{W}-150^{\circ} \mathrm{E}$ is $1.98 \mathrm{~m} \mathrm{~s}^{-1}$ for CCSM3 and $5.33 \mathrm{~m} \mathrm{~s}^{-1}$ for LOVECLIM. TEJ is closely linked to the boreal summer monsoon rainfall over Africa and Asia through the Hadley circulation. We found that TEJ was stronger and shifted northward from its mean position during MIS-5e in CCSM3, consistent with the strong rainfall over the convergence zone between the wind of the Southern and Northern Hemisphere, known as the monsoon trough (Zeng and Guo, 1982). Similarly, Bosman et al. (2012) found a weakened African easterly jet but strengthened TEJ with north and westward extensions. Therefore, strong TEJ could be a dominating factor for stronger monsoon over the Indian and African regions. Another important 


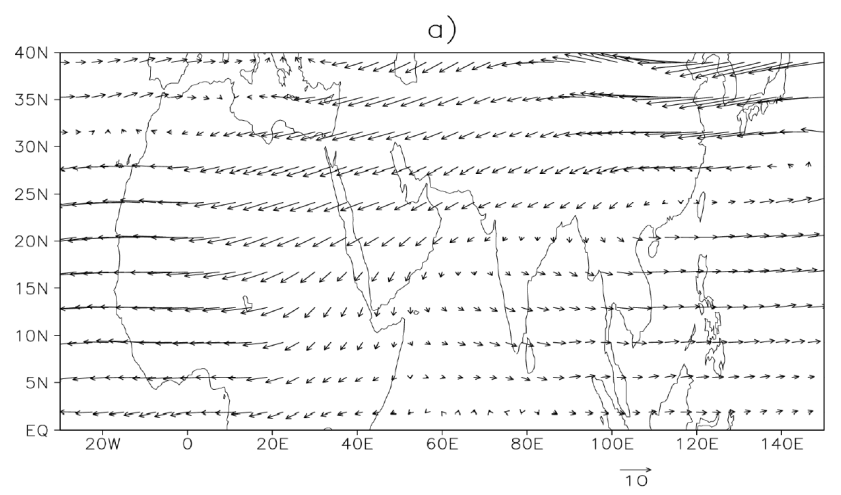

b)

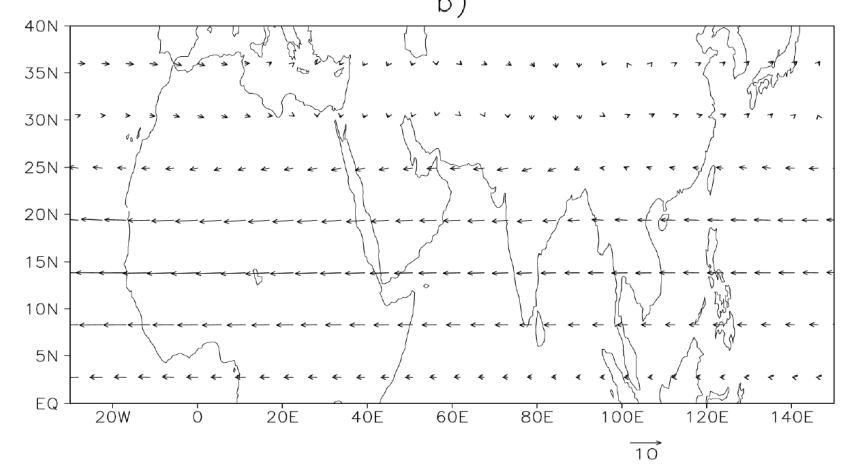

Fig. 9. Tropical easterly jet $\left(\mathrm{m} \mathrm{s}^{-1}\right)$ anomaly at $200 \mathrm{hPa}\left(0-40^{\circ} \mathrm{N}\right.$ and $30^{\circ} \mathrm{W}-150^{\circ} \mathrm{E}$ ) in (a) CCSM3 and (b) LOVECLIM.

component of the summer monsoon circulation is the upperlevel monsoon ridge (in the $200 \mathrm{hPa}$ geopotential height), which normally extends from the Middle East eastward to southeastern Asia. The northward shift of the strong gradient indicates a strong divergence in the upper troposphere which supports the strong monsoon meridional vertical circulation and heavy rainfall over that region. An anomalous high over central Europe, a low over the western Siberia plain and a major high anomaly over northeastern Asia depict a wave train that has an equivalent barotropic structure in the midlatitudes. The specific humidity anomaly seen at low level favors also the heavy rain simulated over Africa, India and east Asia. There is more monsoon precipitation in the $\mathrm{NH}$ during MIS-5e in LOVECLIM than in CCSM3 (Table 4). The circulation monsoon Hadley index (MHI) being used to characterize the Indian monsoon is defined as the meridional wind shear between 850 and $200 \mathrm{hPa}$, averaged over a region extending from 70 to $110^{\circ} \mathrm{E}$ and from 10 to $30^{\circ} \mathrm{N}$. This index represents the strength of the regional monsoon Hadley circulation and is a useful diagnostic tool for studying the monsoon variability of the past (Goswami et al., 1999). The estimated MHI in CCMS3 is 4.25 during MIS-5e and 2.31 during PI, showing a stronger regional monsoon Hadley circulation during MIS-5e. Similarly in LOVECLIM, the MHI is stronger during MIS-5e (1.63) than during PI (1.19).
Table 4. Precipitation anomalies (mm day ${ }^{-1}$, MIS-5e minus PI) over east Asia $\left(20-40^{\circ} \mathrm{N} ; 95-145^{\circ} \mathrm{E}\right)$, India $\left(6.5-37.5^{\circ} \mathrm{N}\right.$; $\left.67.5-101.5^{\circ} \mathrm{E}\right)$ and Africa $\left(0-30^{\circ} \mathrm{N} ; 15^{\circ} \mathrm{W}-45^{\circ} \mathrm{E}\right)$, simulated by CCSM3 and LOVECLIM.

\begin{tabular}{lll}
\hline & CCSM3 & LOVECLIM \\
\hline East Asia & -0.4 & 0.4 \\
India & 0.75 & 2.05 \\
Africa & 1.7 & 3.2 \\
\hline
\end{tabular}

A major precipitation difference between the two models is found over the tropical Indian Ocean, tropical central Pacific Ocean, tropical Atlantic Ocean, North America and east Asia. For example over east Asia, in LOVECLIM, summer precipitation increases over southern and eastern China and over Japan during MIS-5e when compared to PI. This is in agreement with some proxy records. For example, stalagmite from eastern China (Wang et al., 2008) and lake sediments from Japan (Xiao et al., 1999) indicate stronger summer monsoon precipitation during MIS-5e than today. However, CCSM3 simulates less summer precipitation over eastern China and Japan during MIS-5e than PI.

\subsection{DJF precipitation anomalies}

In DJF, both CCSM3 and LOVECLIM simulate more rain during MIS-5e over the Indian Ocean, the western Pacific, the northeastern and the southeastern Pacific, but less over the subtropical southern continents (South America, central Africa, and Australia) (Fig. 10). The weakening of the southern summer monsoon during MIS-5e is in agreement with the modeling results of Montoya et al. (2000) and with some proxy records. For example, Tofalo et al. (2011) conclude a drier MIS-5e in Argentina based on their analysis of loess/paleosols records. High pollen concentrations and high percentage of henopodiaceae/Amaranthaceae from Lake Titicaca (Bolivia/Peru) indicate warmth and aridity during MIS5e (Fritz et al., 2007). Zhao et al. (2001) show that the stalagmite growth in western Australia during MIS-5e was slow, implying dry conditions. Ayliffe et al. (1998) discuss that during interglacials and warm interstadials the southeastern part of Australia was comparatively arid. Therefore, both model simulations and proxy data show a weakened monsoon precipitation in the SH during MIS-5e compared to PI.

\section{Vegetation}

Over Africa (between the Equator and $30^{\circ} \mathrm{N}$ ), the increase of tree fraction during MIS-5e as compared to PI is larger in LOVECLIM than in BIOME4 (Fig. 11a and d). Grassland simulated in BIOME4 (Fig. 11b) occupies about $80 \%$ of the land at $20^{\circ} \mathrm{N}$, while LOVECLIM simulates about $50 \%$, the rest being mainly trees (Fig. 11e). On the one hand, 


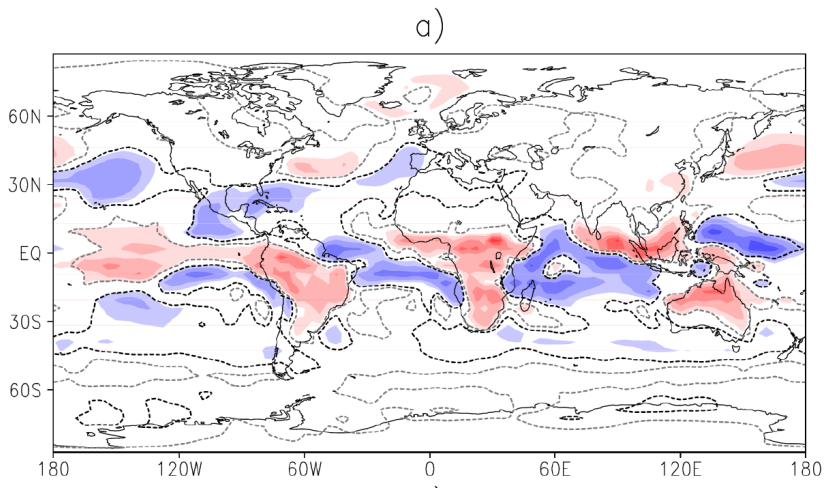

b)

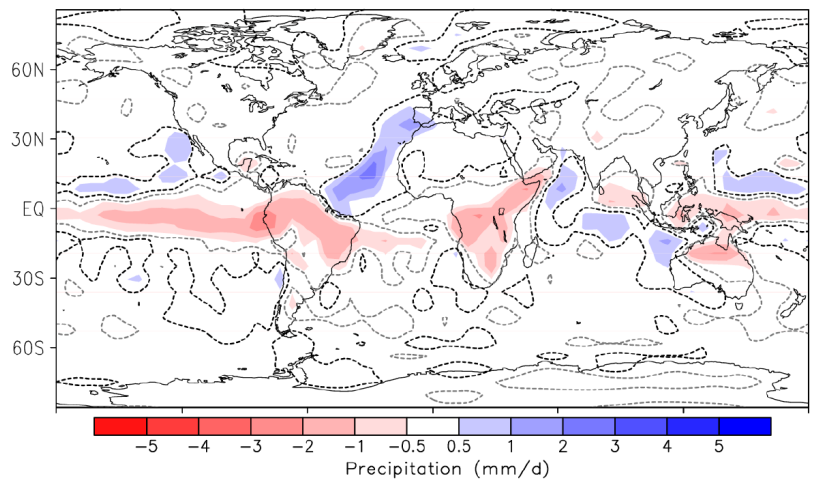

Fig. 10. DJF precipitation $\left(\mathrm{mmday}^{-1}\right)$ anomaly simulated by (a) CCSM3 and (b) LOVECLIM. Precipitation anomaly between black and grey dashed lines is statistically insignificant.

this difference between the two models could be related to the fact that the vegetation-climate feedbacks are missing in CCSM3 due to the lack of a dynamic vegetation model. On the other hand, it could be related to the fact that LOVECLIM tends to overestimate the precipitation around $30^{\circ} \mathrm{N}$ and the temperature in the tropics (Goosse et al., 2010) and therefore to amplify the vegetation response. This has also been reflected in the inter-model comparison for the mid-Holocene climate (Braconnot et al., 2007). The expansion of the vegetated area during MIS-5e in Sahel/Sahara in LOVECLIM, which results from the northward shift of the ITCZ and moisture advection, is in line with proxy records showing wetter, greener and more vegetated Sahel/Sahara (Jolly et al., 1998).

Simulated grass is also more developed over Europe, Asia and central North America (between 30 and $60^{\circ} \mathrm{N}$ ) in BIOME4 during MIS-5e than in LOVECLIM. The abundance of grass and decrease of forest in BIOME4 could be associated with colder annual climate and negative precipitation anomaly in CCSM3, which could affect the distribution of vegetation. LOVECLIM simulates warmer annual climate and positive precipitation anomaly with higher tree fraction between the Equator and $45^{\circ} \mathrm{N}$ and similar between 45 and $60^{\circ} \mathrm{N}$ to its PI level, in line with proxy data showing a well-established mixed forest in Europe (Kukla et al., 2002; Shackleton et al., 2003). The simulation of BIOME4 over the Chinese Loess Plateau shows temperate deciduous forest, temperate conifer forest and warm mixed forest in the south and central part of the Loess Plateau, and cool mixed forest, shrubland and grassland in the northwestern part. The simulation of LOVECLIM shows that trees are mainly developed in the southern region $(>50 \%$ ) while grass occupies more space in the northwestern part. Both model simulations are found in agreement with proxy data over the Chinese Loess Plateau showing a mixture of steppe and forest (Cai et al., 2013).

To the north (between 60 and $70^{\circ} \mathrm{N}$ ), wetter and warmer climate promotes the growth and northward shift of boreal forest in both models (Fig. 11a and d). Based on fossil pollen data, Anderson et al. (2006) report that the boreal forests experienced "dramatic poleward expansions". Tundra, grass and forest (proxy data indicate mainly birch forest) flourished on the western and eastern sides of Greenland. Notable northward shift of boreal forest across the Arctic is also reported in Saarnisto et al. (1999) for Scandinavia, in Lozhkin et al. (2007) for Siberia and in Edwards et al. (2003) for Alaska.

A large reduction in deserts, as compared to PI, is simulated by both BIOME4 and LOVECLIM over the $\mathrm{NH}$ (Fig. 11c and f). Over the Southern Hemisphere, good agreement is also found between the two models. The increase in desert between the Equator and $30^{\circ} \mathrm{S}$ is attributed to the annual warming and decreased precipitation over Australia.

\section{Mean climate and interannual variability of the tropical Pacific}

To study the changes in the mean climate of the tropical Pacific, the annual mean of equatorial tropical Pacific SST, zonal wind stress and mean tilt of the thermocline are averaged over $5^{\circ} \mathrm{S}-5^{\circ} \mathrm{N}$ between 150 and $275^{\circ} \mathrm{E}$ and analyzed. In the CCSM3 simulations, MIS-5e SST shows a westward shift in the Pacific cold tongue (minimum SST), an eastward shift of the warm pool (maximum SST) and a cooling mainly in the central Pacific relative to the PI (Fig. 12a). The eastwest SST difference (difference between cold tongue and warm pool) increases slightly from $4{ }^{\circ} \mathrm{C}$ in PI to $4.2^{\circ} \mathrm{C}$ in MIS-5e. This is not the case for LOVECLIM, which shows, in both MIS-5e and PI, an east-west SST difference of $2{ }^{\circ} \mathrm{C}$. The weakness of LOVECLIM in the tropics (as identified by Goosse et al., 2010) is a too high temperature over the continents and in the eastern Pacific which leads to a reduced temperature gradient between the eastern and the western Pacific in comparison with observations. As for atmosphere dynamics, LOVECLIM does not capture the atmosphere equatorial Kelvin wave dynamics and uses ageostrophic parameterizations for the Hadley circulation. In an attempt to solve at least partly these deficiencies, Sriver et al. (2013) have introduced the effect of the divergent winds on the stream function through the balance equation, an effect which attempts 

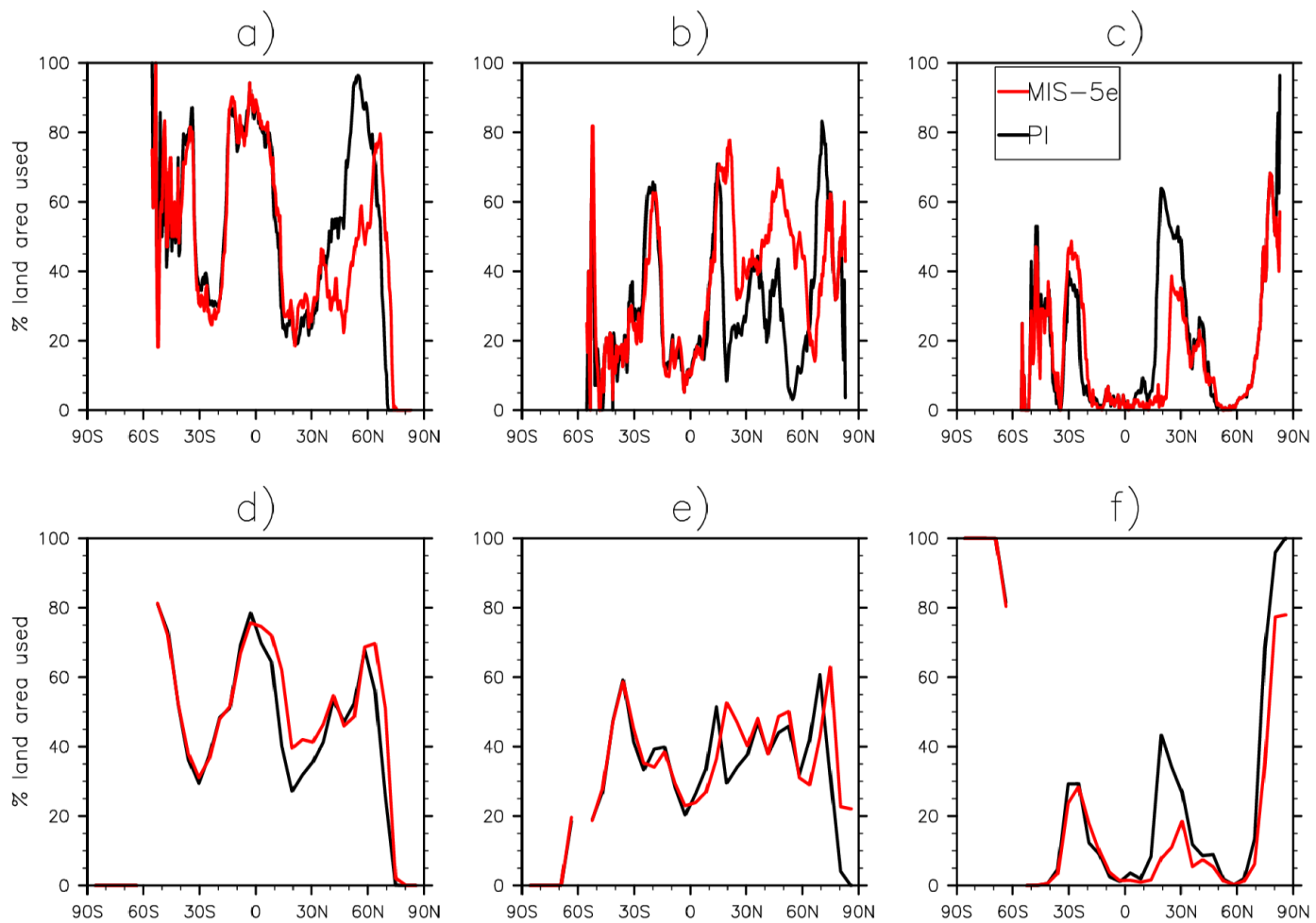

Fig. 11. Vegetation fraction (\%) simulated by BIOME4 for (a) trees, (b) grass, (c) desert and by LOVECLIM for (d) trees, (e) grass, (f) desert. BIOME4 trees include the following vegetation: tropical evergreen forest, tropical semi-deciduous forest, tropical deciduous forest/woodland, temperate deciduous forest, temperate conifer forest, warm mixed forest, cool mixed forest, cool conifer forest, cold mixed forest, evergreen taiga forest, deciduous taiga forest, tropical savanna, temperate broadleaved savanna, open conifer woodland, temperate sclerophyll woodland. BIOME4 grass includes the following: tropical xerophytic shrubland, temperate xerophytic shrubland, tropical grassland, temperate grassland, boreal parkland, steppe tundra, shrub tundra, dwarf shrub tundra, prostrate shrub tundra, cushion forbs, lichen and moss. BIOME4 desert includes desert, barren and land ice.

to solve the misrepresentation of the equatorial trade winds. Unfortunately the weak atmospheric resolution and a badly parameterized convection scheme prevent solving the problem completely. In addition, it cools the equatorial regions and reduces the latitudinal temperature gradient. According to A. Timmermann (personal communication, 2012), resolving deep convection seems to be the key problem.

For CCSM3, the zonal wind stress shows a very slight decrease mainly in the eastern and western sides in MIS-5e (Fig. 12b). In LOVECLIM, however, there is a significant increase in the MIS-5e zonal wind stress when compared to PI. The mean thermocline depth (depth of the largest vertical temperature gradient) is approximated by the depth of the $20^{\circ} \mathrm{C}$ isotherm as is usually done by model studies of $\mathrm{PI}$ and also found to be a good approximation for MIS-5e. In CCSM3, there is almost no difference in the thermocline between MIS-5e and PI (Fig. 12c), which is consistent with the very small difference in the zonal wind stress. In contrast, LOVECLIM shows a much deeper thermocline for MIS-5e especially in the western part. Based on the finding of Timmermann et al. (2005), we suggest that this deepening of the thermocline is an ocean-related process most likely caused by its re-adjustment to the weakening of the Atlantic meridional circulation (AMOC) as mentioned earlier. The thermocline deepening occurring only in LOVECLIM but not in CCSM3 might be related to the difference in their atmosphere resolutions. Indeed, in response to AMOC weakening, more complex models exhibit a change in their atmospheric circulation, which in turn causes a shoaling of the thermocline and restrains the thermocline from deepening through oceanic processes (Timmermann et al., 2007a).

For the interannual variability around the mean state discussed above, the last 1200 months of SSTs were analyzed. We focus on the so-called NIÑO3.4 region $\left(5^{\circ} \mathrm{S}-5^{\circ} \mathrm{N} ; 190\right.$ $240^{\circ} \mathrm{E}$ ) and the SST averaged over this region. The monthly mean cycle was resolved, and a 12-month moving average filter was applied following Douglass (2011). The NIÑO3.4 SST variability in the LOVECLIM simulations is particularly small (Fig. 13b). This is because the overestimated deep thermocline in LOVECLIM diminishes the SST variability. Underestimated SST variability in LOVECLIM was also mentioned by Goosse et al. (2010). We will, therefore, mainly discuss the ENSO characteristics of the CCSM3 experiments. 

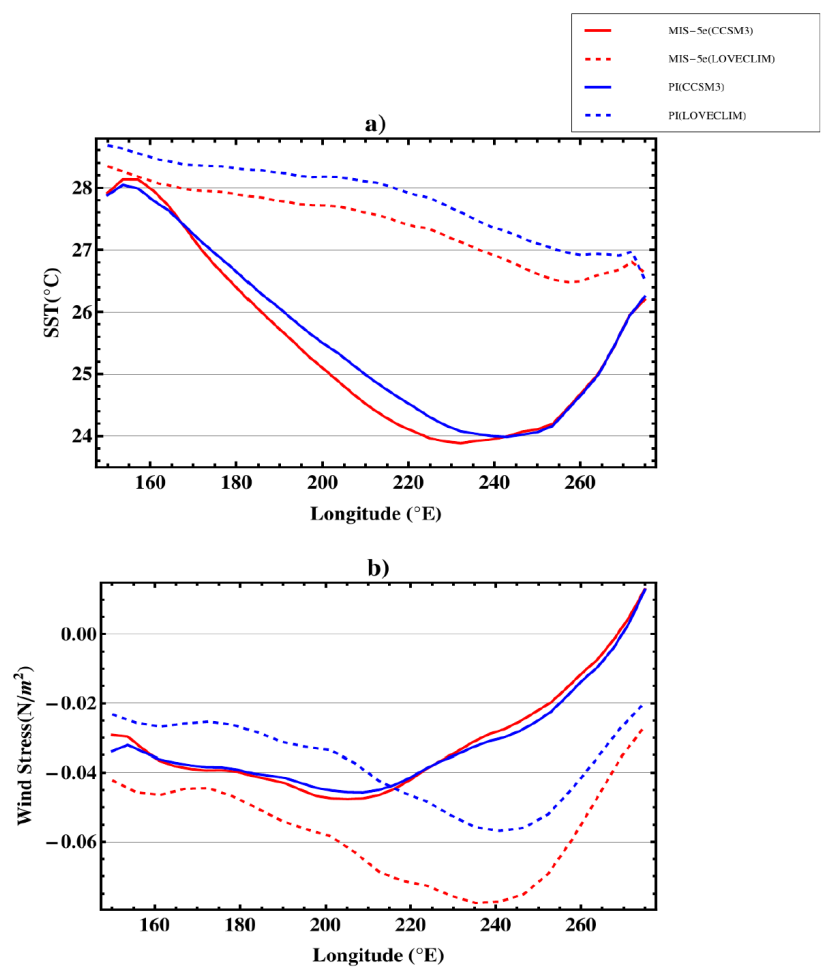

c)

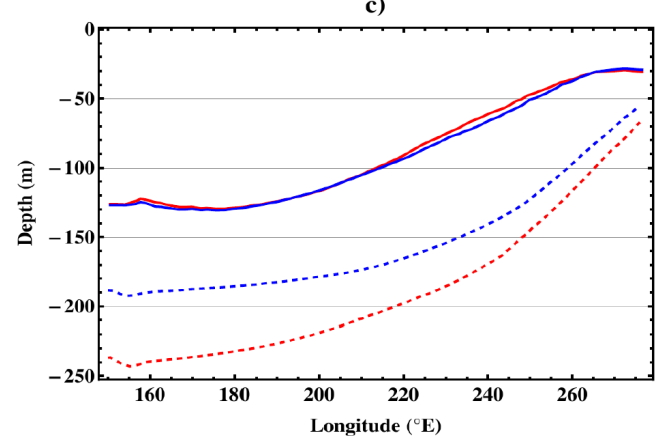

Fig. 12. CCSM 3 and LOVECLIM simulations averaged over $5^{\circ} \mathrm{S}-$ $5^{\circ} \mathrm{N}$ between 150 and $275^{\circ} \mathrm{E}$ of (a) SST $\left({ }^{\circ} \mathrm{C}\right)$, (b) wind stress $(\mathrm{Pa})$ and (c) depth of the thermocline (m).

The spectrum of the SST NIÑO3.4 anomalies shows dominant variability at interannual timescale which is related to ENSO (Fig. 13a). The power spectrum for PI has large and significant magnitude in the $1.7-6.5 \mathrm{yr}$ band with the largest peak around $3.7 \mathrm{yr}$. We also find the largest peak of the spectrum at period around 2-3 yr when we apply a 5-month moving average filter. This is consistent with some other CCSM3 model studies where a period of around $2 \mathrm{yr}$ for ENSO variability was found (e.g., Merkel et al., 2010). In the MIS$5 \mathrm{e}$ run, the large and significant peaks of the spectrum are limited to a $2-6$ yr band, while the leading period is around $2.1 \mathrm{yr}$. The largest peak of the power spectrum in MIS-5e has a shorter period compared to the one in PI and its magnitude is slightly larger $(\sim 10 \%)$. This shorter period during MIS-5e might be partially related to the westward shift of

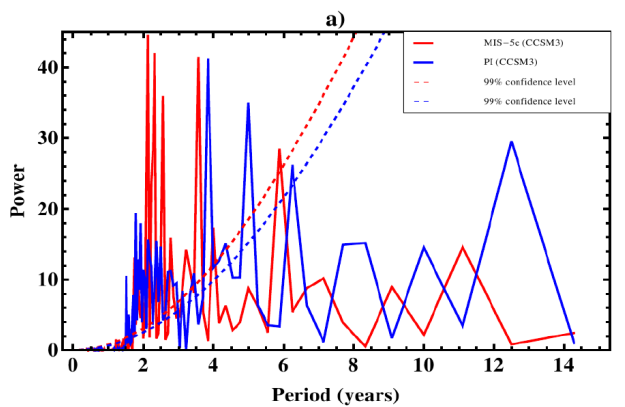

b)

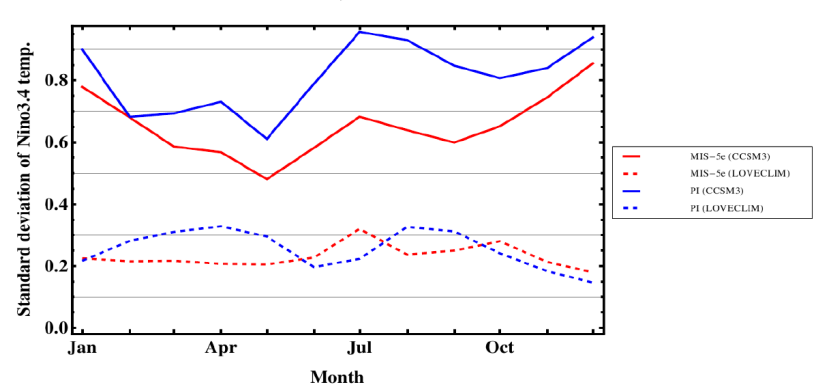

c)

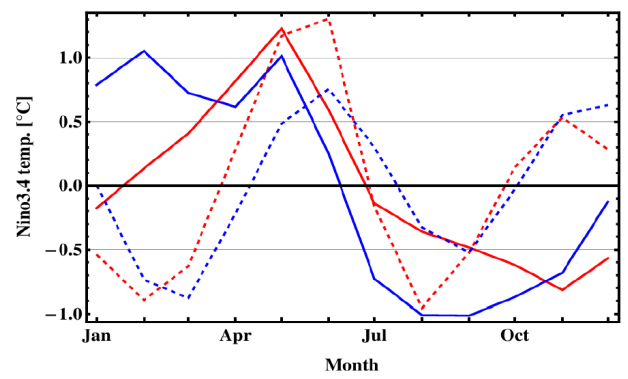

Fig. 13. CCSM3 3 and LOVECLIM results averaged over NIÑO3.4 region $\left(5^{\circ} \mathrm{S}-5^{\circ} \mathrm{N}\right.$ and $\left.190-240^{\circ} \mathrm{E}\right)$ for (a) spectrum for SST anomalies, (b) monthly standard deviation for SST anomalies and (c) monthly SST anomalies.

the cold tongue which reduces the distance between the cold tongue and the warm pool. The moderate change in the magnitude and pattern of the significant peaks in the spectrum of MIS-5e can in some degree be related to the shoaling of the thermocline, the increase of the east-west temperature gradient and the weaker trade winds in the tropical Pacific. However, as shown above, the change in these factors was moderate. It is also of interest to check other factors. Following Timmermann et al. (2007b), the change in the strength and phase of the SST annual cycle (mean value of each month) could be another factor to modify the power spectrum in MIS-5e. This can be further investigated by comparing the annual cycle with the standard deviation of each month as inspired by Merkel et al. (2010). The standard deviation (Fig. 13b) and the mean SST (Fig. 13c) of each month do not follow the same trend (have opposite trend). The standard deviation of the MIS-5e SST is the highest (lowest) in boreal winter (spring), when the amplitude of the annual cycle 
is around its minimum (maximum), which might affect the ENSO variability. Measurement of oxygen isotopes in coral fossils of Bunaken Island (around $120^{\circ} \mathrm{E}$ of the Equator) by Hughen et al. (1999) also showed that the last interglacial had ENSO variability similar to the period 1856-1976.

\section{Conclusions}

In this paper, the last interglacial climate, including surface temperature, hydrological cycle, vegetation and ENSO, was investigated through simulations of two models of different complexity, CCSM3 and LOVECLIM. Broad agreement between both models is found over the continents that remain warmer during summer (except over northern Africa and the Arabian Peninsula) and cooler during winter in MIS5e than PI. Discrepancies between the two models mainly occur in the polar areas, closely related to feedback from sea ice and snow cover. Weakened polar amplification is simulated by CCSM3 that simulates more sea ice in MIS-5e and lower surface temperatures than LOVECLIM. In addition, the reduction in snow cover is much larger in LOVECLIM than in CCSM3, contributing to the larger Arctic warming in LOVECLIM.

Intensification of the African monsoon causes cooling during boreal summer over northern Africa and on the Arabian Peninsula. In MIS-5e the ITCZ moves further north as compared to PI. Precipitation increases over the Sahel/Sahara, over India, Tibet, southwestern China and over the northern part of South America. Deserts reduce largely in the $\mathrm{NH}$ but increase in North Australia due to the annual warming and decreased precipitation. Vegetation (trees) is more developed and abundant in Sahel/Sahara and in mid-latitudes in the LOVECLIM simulation than in BIOME4 and in line with the reported proxy records. In both models trees expand deep into high northern latitudes, found in good agreement with proxy records.

CCSM3 simulates larger tropical Pacific SST for MIS5e than for PI. We suggest this is related to the change in the SST annual cycle next to smaller effects through increased east-west temperature gradient and less-steep thermocline. However the SST variability in our LOVECLIM simulations is particularly small due to the overestimated thermocline's depth, a weakness of LOVECLIM that is to be overcome with modifications addressing oceanic heat uptake (and not only) in the currently ongoing iCLIPS project (Goelzer et al., 2011). All important components and iceclimate interactions necessary to simulate climate and sealevel changes on centennial to millennial timescales would be improved and robustly addressed, helping to reduce the model uncertainties.

The simulated broad-scale climate changes during the last interglacial compare well between the two models. This demonstrates that LOVECLIM, although classified as a climate model of intermediate complexity, is an efficient tool for climate investigations and in comparison with other coupled general circulation models has the advantage of largely reduced computer requirements for climate and sealevel integrations of longer duration and a larger number of sensitivity experiments can be conducted (Goelzer et al., 2011). CCSM3 and LOVECLIM qualitatively simulate the large-scale climate changes in line with proxy records. We should keep in mind that the proxy records are scarce and mostly confined to the $\mathrm{NH}$ and their interpretations are regionally biased. Additional proxy data could increase not only our understanding of the past climate dynamics, but can provide necessary data for model assessment because comparisons between model simulations and proxy data are a key to testing the credibility of the proposed methods.

Acknowledgements. This work and I. Nikolova, U. K. Singh and M. P. Karami are supported by the European Research Council Advanced Grant EMIS (No. 227348 of the program "Ideas"). Q. Z. Yin is supported by the Belgian National Fund for Scientific Research (F. R. S. -FNRS). N. Herold is thanked for the simulations with CCSM3. Access to computer facilities was made easier through sponsorship from S. A. Electrabel, Belgium. Computational resources have been provided by the supercomputing facilities of the Universite Catholique de Louvain (CISM/UCL) and the Consortium des Equipements de Calcul Intensif en Fédération Wallonie Bruxelles (CECI) funded by the Belgian National Fund for Scientific Research (FRS-FNRS).

Edited by: J. C. Hargreaves

\section{References}

Andersen, K. K., Azuma, N., Barnola, J.-M., Bigler, M., Biscaye, P., Caillon, N., Chappellaz, J., Clausen, H. B., Dahl-Jensen, D., Fischer, H., Flückiger, J., Fritzsche, D., Fujii, Y., Goto-Azuma, K., Grønvold, K., Gundestrup, N. S., Hansson, M., Huber, C., Hvidberg, C. S., Johnsen, S. J., Jonsell, U., Jouzel, J., Kipfstuhl, S., Landais, A., Leuenberger, M., Lorrain, R., Masson-Delmotte, V., Miller, H., Motoyama, H., Narita, H., Popp, T., Rasmussen, S. O., Raynaud, D., Rothlisberger, R., Ruth, U., Samyn, D., Schwander, J., Shoji, H., Siggard-Andersen, M.-L., Steffensen, J. P. S., T., Sveinbjörnsdóttir, A. E., Svensson, A., Takata, M., Tison, J.L., Thorsteinsson, T., Watanabe, O., Wilhelms, F., and White, J. W. C.: High-resolution record of Northern Hemisphere climate extending into the last interglacial period, Nature, 431, 147-151, 2004.

Anderson, P., Bermike, O., Bigelow, N., Brigham-Grette, J., Duvall, M., Edwards, M. E., Frechette, B., Funder, S., Johnsen, S., Knies, J., Koerner, R., Lozhkin, A., Marshall, S., Matthiessen, J., Macdonald, G., Miller, G., Montoya, M., Muhs, D., Otto-Bliesner, B., Overpeck, J., Reeh, N., Sejrup, H., Spielhagen, R., Turner, C., and Velichko, A.: Last Interglacial Arctic warmth confirms polar amplification of climate change, Quaternary Sci. Rev., 25, 1383-1400, doi:10.1016/j.quascirev.2006.01.033, 2006.

Andreev, A. A., Grosse, G., Schirrmeister, L., Kuzmina, S. A., Novenko, E. Yu., Bobrov, A. A., Tarasov, P. E., Ilyashuk, B. P., Kuznetsova, T. V., Krbetschek, M., Meyer, H., and Kunitsky, V. 
V.: Late Saalian and Eemian paleoenvironmental history of the Bolshoy Lyakhovsky Island (Laptev Sea region, Arctic Siberia), Boreas, 33, 319-348, 2004.

Ayliffe, L. K., Marianelli, P. C., Moriarty, K. C., Wells, R. T., McCulloch, M. T., Mortimer, G. E., and Hellstrom, J. C.: $500 \mathrm{ka}$ precipitation record from southeastern Australia: evidence for interglacial relative aridity, Geology, 26, 147-150, 1998.

Bauch, H. A., Erlenkeuser, H., Fahl, K., Spielhagen, R. F., Weinelt, M. S., Andruleit, H., and Henrich, R.: Evidence for a steeper MIS5 than Holocene sea surface temperature gradient between Arctic and sub-Arctic regions, Palaeogeogr. Palaeocl., 145, 95117, 1999.

Berger, A.: Long Term Variations of Daily Insolation and Quaternary Climatic Changes, J. Atmos. Sci., 35, 2362-2367, 1978.

Berger, A. and Loutre, M.-F.: Modélisation de la réponse du climat au forçage astronomique et à la concentration en $\mathrm{CO}_{2}$, Comptes rendus de l'Académie des sciences. Série 2. Sciences de la terre et des planètes, 323, 1-16, 1996.

Berger, A. and Yin, Q. Z.: Modelling the past and future interglacials in response to astronomical and greenhouse gas forcing, The Future of the World's Climate, Elsevier, Amsterdam, 437$462,2012$.

Bianchi, S. and Gersonde, R.: The Southern Ocean surface between Marine Isotope Stages 6 and 5d: shape and timing of climate changes, Palaeogeogr. Palaeocl., 187, 151-177, 2002.

Bintanja, R., van de Wal, R. S. W., and Oerlemans, J.: Modelled atmospheric temperatures and global sea levels over the past million years, Nature, 437, 125-128, 2005.

Bosmans, J. H. C., Drijfhout, S. S., Tuenter, E., Lourens, L. J., Hilgen, F. J., and Weber, S. L.: Monsoonal response to midholocene orbital forcing in a high resolution GCM, Clim. Past, 8, 723-740, doi:10.5194/cp-8-723-2012, 2012.

Braconnot, P., Otto-Bliesner, B., Harrison, S., Joussaume, S., Peterchmitt, J.-Y., Abe-Ouchi, A., Crucifix, M., Driesschaert, E., Fichefet, Th., Hewitt, C. D., Kageyama, M., Kitoh, A., Laîné, A., Loutre, M.-F., Marti, O., Merkel, U., Ramstein, G., Valdes, P., Weber, S. L., Yu, Y., and Zhao, Y.: Results of PMIP2 coupled simulations of the Mid-Holocene and Last Glacial Maximum Part 1: experiments and large-scale features, Clim. Past, 3, 261277, doi:10.5194/cp-3-261-2007, 2007.

Braconnot, P., Marzin, C., Grégoire, L., Mosquet, E., and Marti, O.: Monsoon response to changes in Earth's orbital parameters: comparisons between simulations of the Eemian and of the Holocene, Clim. Past, 4, 281-294, doi:10.5194/cp-4-281-2008, 2008.

Briegleb, B. P., Bitz, C. M., Hunke, E. C., Lipscomb, W. H., Holland, M. M., Schramm, J. L., and Moritz, R. E.: Scientific description of the sea ice component in the Community Climate System Model, Version Three, Technical Report NCAR/TN463+STR, National Center for Atmospheric Research, Boulder, CO, 2004.

Brovkin, V.: Climate-vegetation interaction, J. Phys. IV France, 12, 57-72, doi:10.1051/jp4:20020452, 2002.

Brovkin, V., Ganopolski, A., and Svirezhev, Y.: A continuous climate-vegetation classification for use in climate-biosphere studies, Ecol. Model., 101, 251-261, 1997.

Cai, M., Wei, M., Fang, X., Xu, D., Miao, Y., and Wu, F.: Vegetation and climate change during three interglacial periods represented in the Luochuan loess-paleosol section, on the Chinese Loess Plateau, Quartern. Int., 296, 131-140, doi:10.1016/j.quaint.2012.06.041, 2013.

Claussen, M.: On multiple solutions of the atmosphere-vegetation system in present-day climate, Global Change Biol., 4, 549-559, 1998.

Claussen, M., Fohlmeister, J., Ganopolski, A., and Brovkin, V.: Vegetation dynamics amplifies precessional forcing, Geophys. Res. Lett., 33, L09709, doi:10.1029/2006GL026111, 2006.

Collins, W. D., Rasch, P. J., Boville, B. A., Hack, J. J., McCaa, J. R., Williamson, D. L., Kiehl, J. T., Briegleb, B., Bitz, C., Lin, S.-J., Zhang, M., and Dai, Y.: Description of the NCAR Community Atmosphere Model (CAM3), Technical Report NCAR/TN464+STR, National Center for Atmospheric Research, Boulder, Colorado, 226 pp., 2004.

Collins, W., Bitz, C. M., Blackmon, M. L., Bonan, G. B., Bretherton, C. S., Carton, J. A., Chang, P., Doney, S. C., Hack, J. J., Henderson, T. B., Kiehl, J. T., Large, W. G., McKenna, D. S., Santer, B. D. and Smith, R. D.: The Community Climate System Model Version 3 (CCSM3). J Climate, 19, 2122-2143, 2006.

Crosta, X., Sturm, A., Armand, L., and Pichon, J.-J.: Late Quaternary sea ice history in the Indian sector of the Southern Ocean as recorded by diatom assemblages, Mar. Micropaleontol., 50, 209-223, 2004.

Crucifix, M. and Loutre, M.-F.: Transient simulations over the last interglacial period (126-115 kyr BP): feedback and forcing analysis, Clim. Dynam., 19, 417-433, 2002.

de Beaulieu, J.-L. and Reille, M: The last climatic cycle at La Grande Pile (Vosges, France) - a new pollen profile, Quaternary Sci. Rev., 11, 431-438, 1992.

de Noblet, N., Braconnot, P., Joussaume, S., and Masson, V.,: Sensitivity of simulated Asian and African summer monsoons to orbitally induced variations in insolation 126, 115 and $6 \mathrm{kBP}$, Clim. Dynam., 12, 589-603, 1996.

Denman, K. L., Brasseur, G., Chidthaisong, A., Ciais, P., Cox, P. M., Dickinson, R. E., Hauglustaine, D., Heinze, C., Holland, E., Jacob, D., Lohmann, U., Ramachandran, S., da Silva Dias, P. L., Wofsy, S. C., and Zhang, X.: Couplings Between Changes in the Climate System and Biogeochemistry, in: Climate Change 2007: The Physical Science Basis, Contribution of Working Group I to the Fourth Assessment Report of the Intergovernmental Panel on Climate Change, edited by: Solomon, S., Qin, D., Manning, M., Chen, Z., Marquis, M., Averyt, K. B., Tignor, M., and Miller, H. L., Cambridge University Press, Cambridge, UK and New York, NY, USA, 1-1009, 2007.

Douglas, D. H.: Separation of a signal of interest from a seasonal effect in geophysical data: El Niño/La Niña phenomenon, Int. J. Geosci., 2, 414-419, doi:10.4236/ijg.2011.24045, 2011.

Duplessy, J. C., Roche, D. M. and Kageyama, M.: The deep ocean during the last interglacial period. Science, 316, 89-91, doi:10.1126/science.1138582, 2007.

Edwards, M. E., Hamilton, T. D., Elias, S. A., Bigelow, N. H., and Krumhardt, A. P.: Interglacial extension of the boreal forest limit in the Noatak valley, northwest Alaska: evidence from an exhumed river-cut bluff and debris apron, Arct. Antarct. Alp. Res., 35, 460-468, 2003.

Fichefet, T. and Maqueda, M. A.: Sensitivity of a global sea ice model to the treatment of ice thermodynamics and dynamics, J. Geophys. Res., 102, 12609-12646, 1997. 
Fischer, N. and Jungclaus, J. H.: Effects of orbital forcing on atmosphere and ocean heat transports in Holocene and Eemian climate simulations with a comprehensive Earth system model, Clim. Past, 6, 155-168, doi:10.5194/cp-6-155-2010, 2010.

Fritz, S. C., Baker, P. A., Seltzer, G. O., Ballantyne, A., Tapia, P., Cheng, H., and Edwards, R. L.: Quaternary glaciation and hydrologic variation in the South American tropics as recontructed from the Lake Titicaca drilling project, Quaternary Res., 68, 410-420, 2007.

Ganopolski, A., Kubatzki, C., Claussen, M., Brovkin, V., and Petoukhov, V.: The influence of vegetation-atmosphere-ocean interaction on climate during the Mid-Holocene, Science, 280, 1916-1919, 1998.

Gent, P. R., Danabasoglu, G., Donner, L. J., Holland, M. M., Hunke, E. C., Jayne, S. R., Lawrence, D. M., Neale, R. B., Rasch, J., Vertenstein, M., Worley, P. H., Yang, Z. L., and Zhang, M.: The community climate system model version 4, J. Climate, 24, 4973-4991, 2011.

Goelzer, H., Huybrechts, P., Loutre, M.-F., and Fichefet, T.: Constraining long term climate and sea level projections using the last interglacial (iCLIPS). Annual Scientific Report (contract number SD/CS/06A), Science for a Sustainable Development, Belgian Science Policy, Brussels, p. 24, 2011.

Goosse, H. and Fichefet, T.: Importance of ice-ocean interactions for the global ocean circulation: a model study, J. Geophys. Res., 104, 23337-23355, 1999.

Goosse, H., Brovkin, V., Fichefet, T., Haarsma, R., Huybrechts, P., Jongma, J., Mouchet, A., Selten, F., Barriat, P.-Y., Campin, J.M., Deleersnijder, E., Driesschaert, E., Goelzer, H., Janssens, I., Loutre, M.-F., Morales Maqueda, M. A., Opsteegh, T., Mathieu, P.-P., Munhoven, G., Pettersson, E. J., Renssen, H., Roche, D. M., Schaeffer, M., Tartinville, B., Timmermann, A., and Weber, S. L.: Description of the Earth system model of intermediate complexity LOVECLIM version 1.2, Geosci. Model Dev., 3, 603-633, doi:10.5194/gmd-3-603-2010, 2010.

Goswami, B. N., Krishnamurthy, V., and Annamalai, H.: A broadscale circulation index for the interannual variability of the Indian summer monsoon, Q. J. Roy. Meteorol. Soc., 125, 611-633, 1999.

Groll, N., Widmann, M., Jones, J. M., Kaspar, F., and Lorenz, S. J.: Simulated relationships between regional temperatures and large-scale circulation: $125 \mathrm{kyr}$ BP (MIS5) and the preindustrial period, J. Climate, 18, 4032-4055, 2005.

Guan, Q. Y., Pan, B. T., Gao, H. S., Li, B. Y., Wang, J. P., and Su, H.: Instability characteristics of the East Asian Monsoon recorded by high resolution loess sections from the last interglacial (MIS5), Sci. China Ser. D, 50, 1067-1075, 2007.

Hahne, J., Kemle, S., Merkt, J. and Meyer, K.-D.: Eem-,weichselund saalezeitliche Ablagerungen der Bohrung "Quakenbrück GE 2", Geolog. Jahrb. A, 134, 9-69, 1994.

Herold, N., Yin, Q. Z., Karami, M. P., and Berger, A.: Modelling the climatic diversity of the warm interglacials, Quaternary Sci. Rev., 56, 126-141, 2012.

Hodell, D. A., Minth, E. K., Curtis, J. H., McCave, I. N., Hall, I. R., Channell, J. E. T., and Xuan, C.: Surface and deep-water hydrography on Gardar Drift (Iceland Basin) during the last interglacial period, Earth Planet. Sc. Lett., 288, 10-19, 2009.
Holden, P. B., Edwards, N. R., Wolff, E. W., Lang, N. J., Singarayer, J. S., Valdes, P. J., and Stocker, T. F.: Interhemispheric coupling, the West Antarctic Ice Sheet and warm Antarctic interglacials, Clim. Past, 6, 431-443, doi:10.5194/cp-6-431-2010, 2010.

Hughen, K. A., Schrag, D. P., and Jacobsen, S. B.: El Niño during the last interglacial period recorded by a fossil coral from Indonesia, Geophys. Res. Lett., 26, 3129-3132, 1999.

IPCC Fourth Assessment Report: Climate Change 2007, in: Contribution of Working Group I to the Fourth Assessment Report of the Intergovernmental Panel on Climate Change, edited by: Solomon, S., Qin, D., Manning, M., Chen, Z., Marquis, M., Averyt, K. B., Tignor, M., and Miller, H L., Cambridge University Press, Cambridge, UK and New York, NY, USA, http://www. ipcc.ch/publications_and_data/ar4/wg1/en/contents.html (last access: 10 June 2013), 2007.

Jolly, D., Prentice, I. C., Bonnefille, R., Ballouche, A., Bengo, M., Brenac, P., Buchet, G., Burney, D., Cazet, J.-P., Cheddadi, R., Edorh, T., Elenga, H., Elmoutaki, S., Guiot, J., Laarif, F., Lamb, H., Lezine, A.-M., Maley, J., Mbenza, M., Peyron, O., Reille, M., Reynaud-Farrera, I., Riollet, G., Ritchie, J. C., Roche, E., Scott, L., Ssemmanda, I., Straka, H., Umer, M., Van Campo, E., Vilimumbalo, S., Vincens, A., and Waller, M.: Biome reconstruction from pollen and plant macrofossil data for Africa and the Arabian peninsula at 0 and 6000 years, J. Biogeogr., 25, 1007-1027, 1998.

Jouzel, J., Masson-Delmotte, V., Cattani, O., Dreyfus, G., Falourd, S., Hoffmann, G., Minster, B., Nouet, J., Barnola, J. M., Chappellaz, J., Fischer, H., Gallet, J. C., Johnsen, S., Leuenberger, M., Loulergue, L., Luethi, D., Oerter, H., Parrenin, F., Raisbeck, G., Raynaud, D., Schilt, A., Schwander, J., Selmo, E., Souchez, R., Spahni, R., Stauffer, B., Steffensen, J. P., Stenni, B., Stocker, T. F., Tison, J. L., Werner, M., and Wolff, E. W.: Orbital and Millennial Antarctic Climate Variability over the Past 800,000 Years, Science, 317, 793-797, 2007.

Kaplan, J. O., Bigelow, N. H., Prentice, I. C., Harrison, S. P., Bartlein, P. J., Christensen, T. R., Cramer, W., Matveyeva, N. V., McGuire, A. D., Murray, D. F., Razzhivin, V. Y., Smith, B., Walker, D. A., Anderson, P. M., Andreev, A. A., Brubaker, L. B., Edwards, M. E., and Lozhkin, A. V.: Climate change and arctic ecosystems II: Modeling, paleodata-model comparisons, and future projections, J. Geophys. Res., 108, 8171, doi:10.1029/2002JD002559, 2003.

Kubatzki, C., Montoya, M., Rahmstorf, S., Ganopolski, A., and Claussen, M.: Comparison of the last interglacial climate simulated by a coupled global model of intermediate complexity and an AOGCM, Clim. Dynam., 16, 799-814, 2000.

Kukla, G., McManus, J. F., Rousseau, D. D., and Chuine, I.: How long and how stable was the last interglacial?, Quaternary Sci. Rev., 16, 605-612, 1997.

Kukla, G. J., Bender, M. L., de Beaulieu, J. L., Bond, G., Broecker, W. S., Cleveringa, P., Gavin, J. E., Herbert, T. D., Imbrie, J., Jouzel, J., Keigwin, L. D., Knudsen, K. L., McManus, J. F., Merkt, J., Muhs, D. R., Muller, H., Poore, R. Z., Porter, S. C., Seret, G., Shackleton, N. J., Turner, C., Tzedakis, P. C., and Winograd, I. J.: Last Interglacial Climates. Quaternary Res., 58, 2-13, doi:10.1006/qres.2001.2316, 2002. 
Labeyrie, L., Labracherie, M., Gorfti, N., Pichon, J. J., Vautravers, M., Arnold, M., Duplessy, J.-C., Paterne, M., Michel, E., Duprat, J., Caralp, M., and Turon, J.-L.: Hydrographic changes of the Southern Ocean (souteast Indian sector) over the last $230 \mathrm{kyr}$, Paleoceanography, 11, 57-76, 1996.

Lozkhin, A. and Anderson, P.: The last interglaciation in northeast Siberia, Quaternary Res., 43, 147-158, 1995.

Lozhkin, A. V., Anderson, P. M., Matrosova, T. V., and Minyuk, P. S.: The pollen record from El'gygytgyn Lake: implications for vegetation and climate histories of northern Chukotka since the late middle Pleistocene, J. Paleolimnol., 37, 135-153, 2007.

Lunt, D. J., de Noblet-Ducoudre, N., and Charbit, S.: Effects of a melted greenland ice sheet on climate, vegetation, and the cryosphere, Clim. Dynam., 23, 679-694, 2004.

Lunt, D. J., Abe-Ouchi, A., Bakker, P., Berger, A., Braconnot, P., Charbit, S., Fischer, N., Herold, N., Jungclaus, J. H., Khon, V. C., Krebs-Kanzow, U., Langebroek, P. M., Lohmann, G., Nisancioglu, K. H., Otto-Bliesner, B. L., Park, W., Pfeiffer, M., Phipps, S. J., Prange, M., Rachmayani, R., Renssen, H., Rosenbloom, N., Schneider, B., Stone, E. J., Takahashi, K., Wei, W., Yin, Q., and Zhang, Z. S.: A multi-model assessment of last interglacial temperatures, Clim. Past, 9, 699-717, doi:10.5194/cp-9-699-2013, 2013.

Mamakowa, K.: Late Middle Polish glaciation, Eemian and Early Vistulian vegetation at Imbramowice near Wroclaw and the pollen stratigraphy of this part of the Pleistocene in Poland, Acta Palaeobot., 29, 11-176, 1989.

Masson-Delmotte, V., Stenni, B., Pol, K., Braconnot, P., Cattani, O., Falourd, S., Kageyama, M., Jouzel, J., Landais, A., Minster, B., Barnola, J. M., Chappellaz, J., Krinner, G., Johnsen, S., Röthlisberger, R., Hansen, J., Mikolajewicz, U., and OttoBliesner, B.: EPICA Dome C record of glacial and integlacial intensities, Quaternary. Sci. Rev., 29, 113-128, 2010.

McKay, N. P., Overpeck, J. T., and Otto-Bliesner, B. L.: The role of ocean therma; expansion in last interglacial sea level rise, Geophys. Res. Lett., 38, L14605, doi:10.1029/2011GL048280, 2011.

Merkel, U., Prange, M., and Schulz, M.: ENSO variability and teleconnestions during glacial climates, Quaterrnary Sci. Rev., 29, 86-100, 2010.

Montoya, M., von Storch, H., and Crowley, T. J.: Climate simulation for $125 \mathrm{kyr} \mathrm{BP}$ with a coupled ocean-atmosphere general circulation model, J. Climate, 13, 1057-1072, doi:10.1175/15200442(2000)013<1057:CSFKBW>2.0.CO;2, 2000.

Muhs, D., Ager, T. A., and Beget, J. E.: Vegetation and paleoclimate of the lastinterglacial period, central Alaska, Quaternary Sci. Rev., 20, 41-61, 2001.

Oleson, K. W., Dai, Y., Bonan, G. B., Bosilovich, M., Dickinson, R., Dirmeyer, P., Hoffman, F., Houser, P., Levis, S., Niu, G.-Y., Thornton, P., Vertenstein, M., Yang, Z.-L., and Zeng, X.: Technical description of the Community Land Model (CLM), Technical Report NCAR/TN-461+STR, National Center for Atmospheric Research, Boulder, CO, 174 pp., 2004.

Oppo, D. W., Keigwin, L. D., and McManus, J. F.: Persistent subtropical climate variability in marine isotope stage 5 and Termination II, Paleoceanography, 16, 280-292, 2001.

Opsteegh, J. D., Haarsma, R. J., Selten, F. M., and Kattenberg, A.: ECBILT: A dynamic alternative to mixed boundary conditions in ocean models, Tellus A, 50, 348-367, 1998.
Otto-Bliesner, B., Marshall, S. J., Miller, G. H., Hu, A., and CAPE Last Interglacial Project members: Simulating Arctic climate warmth and icefield retreat in the last interglaciation, Science, 311, 1751-1753, doi:10.1126/science.1120808, 2006a.

Otto-Bliesner, B. L., Tomas, R., Brady, E. C., Ammann, C., Kothavala, Z., and Clauzet, G.: Climate sensitivity of moderateand low-resolution versions of CCSM3 to preindustrial forcings, J. Climate, 19, 2567-2583, 2006b.

Pahnke, K., Zahn, R., Elderfield, H., and Schulz, M.: 340,000-year centennial scale marine record of Southern Hemisphere climatic oscillation, Science, 301, 948-952, 2003.

Petit, J. R., Jouzel, J., Raynaud, D., Barkov, N. I., Barnola, J.-M., Basile, I., Benders, M., Chappellaz, J., Davis, M., Delaygue, G., Delmotte, M., Kotlyakov, V. M., Legrand, M., Lipenkov, V. Y., Lorius, C., Pépin, L., Ritz, C., Saltzmann, E., and Stievenard, M.: Climate and atmospheric history of the past 420,000 years from Vostok ice core, Antarctica, Nature, 399, 429-436, 1999.

PMIP3: Paleoclimate Modelling Intercomparison Project Phase III, http://pmip3.lsce.ipsl.fr/, last access: 10 June 2013.

Porter, S. C.: Chinese loess record of monsoon climate during the last glacial-interglacial cycle, Earth-Sci. Rev., 54, 115-128, 2001.

Prell, W. L. and Kutzbach, J. E.: Monsoon Variability over the Past 150,000 Years, J. Geophys. Res., 92, 8411-8425, 1987.

Saarnisto, M., Eriksson, B., and Hirvas, H.: Tepsankumpu revisitedpollen evidence of stable MIS5 climates in Finnish Lapland, Boreas, 28, 12-22, 1999.

Shackleton, N. J., Sanchez-Goni, M. F., Pailler, D., and Lancelot, Y.: Marine isotope substage 5e and the MIS5 interglacial, Global Planet. Change, 36, 151-155, doi:10.1016/S09218181(02)00181-9, 2003.

Smith, R. D. and Gent, P. R.: Reference manual for the Parallel Ocean Program (POP), ocean component of the Community Climate System Model (CCSM2.0 and 3.0), Technical Report LAUR-02-2484, Los Alamos National Laboratory, available online at http://www.ccsm.ucar.edu/models/ccsm3.0/pop (last access: 1 October 2012), 2002.

Sriver, R. L., Timmermann, A., Mann, M. E., Keller, K., and Goosse, H.: Improved representation of tropical Pacific oceanatmosphere dynamics in a coarse resolution Earth system model, J. Climate, submitted, 2013.

Timmermann, A., An, S.-I., Krebs, U., and Goosse, H.: Enso suppression due to weakening of the north atlantic thermohaline circulation, J. Climate, 18, 3122-3139, doi:10.1175/JCLI3495.1, 2005.

Timmermann, A., Okumura, Y., An, S.-I., Clement, A., Dong, B., Guilyardi, E., Hu, A., Junglaus, J. H., Renold, M., Stocker, T. F., Stouffer, R. J., Sutton, R., Xie, S.-P., and Yin, J.: The Influence of a Weakening of the Atlantic Meridional Overturning Circulation on ENSO, J. Climate, 20, 4899-4919, doi:10.1175/JCLI4283.1, 2007a.

Timmermann, A., Lorenz, S. J., An, S.-I., Clement, A., and Xie, S.-P.: The effect of orbital forcing on the mean climate and variability of the tropical Pacific, J. Climate, 20, 4147-4159, doi:10.1175/JCLI4240.1, 2007b.

Tofalo, O., Orgeira, M. J., Compagnucci, R., Alonso, M. S., and Ramos, A.: Characterization of a loess-lapeosols section including a new record of the last interglacial stage in Pampean plain, Argentina, J. S. Am. Eatrh Sci., 31, 81-92, 2011. 
Turney, C. S. M. and Jones, R. T.: Does the Agulhas Current amplify global temperatures during super-interglacials?, J. Quaternary Sci., 25, 839-843, 2010.

Wang, Y., Cheng, H., Edwards, R. L., Kong, X., Shao, X., Chen, S., Wu, J., Jiang, X., Wang, X., and An, Z.: Millennial and orbital scale changes in the East Asian monsoon over the past 224,000 years, Nature, 451, 1090-1093, 2008.

Xiao, J. L., An, Z. S., Liu, T. S., Inouchi, Y., Kumai, H., Yosihikawa, S., and Kondo, Y.: East Asian mosoon variation during the last 130,000 years evidence from the Loess Plateau of central China and Lake Biwa of Japan, Quaternary Sci. Rev., 18, 147157, 1999.

Yeager, S. G., Shields, C. A., Large, W. G., and Hack, J. J.: The low-resolution CCSM3, J. Climate, 19, 2545-2566, 2006.

Yin, Q. Z.: Insolation-induced mid-Brunhes transition in Southern Ocean ventilation and deep-ocean temperature, Nature, 494, 222-225, doi:10.1038/nature11790, 2013.
Yin, Q. Z. and Berger, A.: Insolation and $\mathrm{CO}_{2}$ contribution to the interglacial climate before and after the Mid-Brunhes Event, Nat. Geosci., 3, 243-246, 2010.

Yin, Q. Z. and Berger, A.: Individual contribution of insolation and CO2 to the interglacial climates of the past 800,000 years, Clim. Dynam., 38, 709-724, 2012.

Zeng, Z. and Guo, Q.: The relationship between the summer precipitation over Asia-Africa monsoon regions and the tropical easterly jet stream, Chin. J. Atmos. Sci., 6, 283-292, 1982.

Zhao, J.-X., Xia, Q., and Collerson, K. D.: Timing and duration of the Last Interglacial inferred from high resolution U-seris chronology of stalagmite growth in Southern Hemisphere, Earth Planet. Sc. Lett., 184, 635-644, 2001. 